\title{
OSTI
}

\section{Westinghouse Hanford Company Safety Analysis Reports and Technical Safety Requirements Upgrade Program}

D. M. Busche

Date Published

September 1995

Prepared for the U.S. Department of Energy Assistant Secretary for Environmental Management

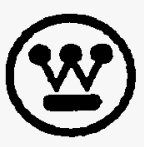

U.S. Department of Energy under Contract DE-AC06-87RL10930 
LEGAL DISCLAMMER

This report was prepared as an account of work sponsored by an agency of the United States Government. Neither the United States Government nor any agency thereof, nor any of their employees, nor any of their contractors, subcontractors or their employees, makes any warranty, express or implied, or assumes any legal liability or responsibility for the accuracy, completeness, or any third party's use or the results of such use of any information, apparatus, product, or process disclosed, or represents that its use would not infringe privstely owned rights. Reference herein to any specific commercial product, process, or service by trade name, trademark, manufacturer, or otherwise, does not necessarily constitute or imply its endorsement, recommendation, or favoring by the United States Government or any agency thereof or its contractors or subcontractors. The views and opinions of authors expressed herein do not necessarily state or reflect those of the United Stetes Government or any agency thereof.

This report has been reproduced from the best available copy. Available in peper copy and microfiche.

Available to the U.S. Department of Energy

and its contractors from

Office of Scientific and Technical Information

P.O. Box 62

Oak Ridge, TN 37831

(615) 576-8401

Available to the public from the U.S. Department of Commerce National Technical Information Service

5285 Port Royal Road

Springfield, VA 22161

(703) $487-4650$

Printed in the United States of America

DISCLM-1.CHP (1-91) 


\section{DISCLAIMER}

Portions of this document may be illegible in electronic image products. Images are produced from the best available original document. 


\section{RELEASE AUTHORIZATION}

Document Number: WHC-SP-1164

Document Title: Westinghơuse Hanford Company Safety AnaTysis Reports and Technical Safety Requirements Upgrade Program

\section{Reloase Date: 10/3/95}

This document was reviewed following the procedures described in WHC-CM-3-4 and is:

\section{APPROVED FOR PUBLIC RELEASE}

WHC Information Rolease Administration Speclalist:

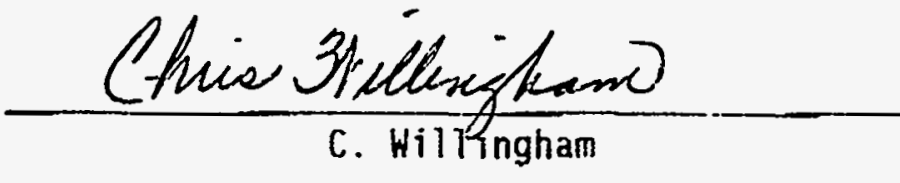

$10 / 3 / 95$

TRADEMARK DISCLAIMER. Reference here in to any specific commercial product, process, or service by trade name, trademark, manufacturer, or otherwise, does not necessarily constitute or imply its endorsement, recommendation, or favoring by the United States Government or any agency thereof or its contractors or subcontractors.

This report has been reproduced from the best available copy. Available in paper copy. Printed in the United States of America. To obtain copies of this report, contact:

Westinghouse Hanford Company - Document Control Services P.O. Box 1970, Mailstop H6-08, Richland, HA 99352

Telephone: (509) 372-2420; Fax: (509) 376-4989 
WHC-SP-1164

Document Title: WESTINGHOUSE HANFORD COMPANY SAFETY ANALYSIS REPORTS AND TECHNICAL SAFETY REQUIREMENTS UPGRADE PROGRAM

Prepared by: $\quad \frac{\text { NolBownie, }}{\text { D. M. Busch }}$

Nuclear Safety Regulatory Compliance

Approved by:

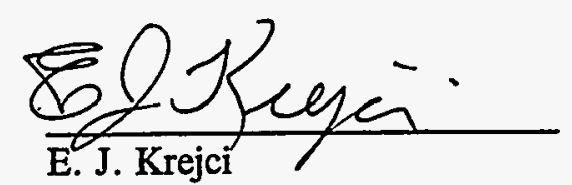

Manager, Nuclear Safety Programs

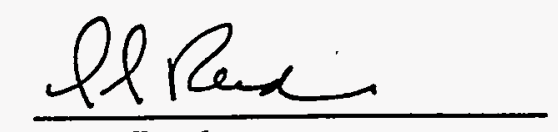

L. L. Reed

Director, Safety

Dilincoze

D. M. Lucoff

Manager, Nuclear Safety Regulatory Compliance $\frac{9 / 25 / 95}{\text { Date }}$

$9 / 28 / 95$

$\frac{9 / 28 / 95}{\text { Date }}$

$\frac{9 / 28 / 95}{\text { Date }}$ 


\section{WHC-SP-1164}

\section{EXECUTIVE SUMMARY}

During Fiscal Year 1992, the U.S. Department of Energy, Richland Operations Office (RL) separately transmitted the following U.S. Department of Energy (DOE) Orders to Westinghouse Hanford Company (WHC) for compliance:

- $\quad$ DOE 5480.21, "Unreviewed Safety Questions,"

- DOE 5480.22, "Technical Safety Requirements," and

- $\quad$ DOE 5480.23, "Nuclear Safety Analysis Reports."

WHC has proceeded with its impact assessment and implementation process for the Orders. The Orders are closely-related and contain some requirements that are either identical, similar, or logically-related. Consequently, WHC has developed a strategy calling for an integrated implementation of the three Orders. The strategy is comprised of three primary objectives, namely:

- Obtain DOE approval of a single list of DOE-owned and WHC-managed Nuclear Facilities, - $\quad$ Establish and/or upgrade the "Safety Basis" for each Nuclear Facility, and

- Establish a functional Unreviewed Safety Question (USQ) process to govern the management and preservation of the Safety Basis for each Nuclear Facility.

WHC has developed policy-revision and facility-specific implementation plans to accomplish nearterm tasks associated with the above strategic objectives. Plans are not provided for all of the deliverables required by the Orders, since some plans cannot be accurately scoped prior to completion of initial tasks. For example, the Orders require contractors to provide "a basis for interim operation and restrictions on interim operations" for existing facilities, as well as a plan for upgrading SARs and developing TSRs in accordance with the new format and content-requirements. WHC plans to prepare "Interim Safety Basis" documents (ISBs) to satisfy the former requirement and the ISBs will provide a reasonable basis for planning for the SAR and TSR upgrades.

This plan, which was originally submitted in August 1993 and approved, provided an interpretation of the new DOE Nuclear Facility definition and an initial list of WHC-managed Nuclear Facilities. For each current existing Nuclear Facility, existing Safety Basis documents are identified and the plan/status is provided for the ISB. Plans for upgrading SARs and developing TSRs will be provided after issuance of the corresponding Rules.

This plan is an update to the approved Implementation Plan for DOE Orders 5480.21, 5480.22, and 5480.23 (Saget). The plan has been restructured to meet the guidelines of DOE-STD-1082-94, Preparation, Review, and Approval of Implementation Plans for Nuclear Safety Requirements to facilitate the upgrade of the plan when the corresponding Nuclear Safety Regulation is promulgated. The facility-specific sections have been restructured to meet the guidelines of the DOE-STD-3011-94, Guidance for Preparation of DOE 5480.22 (TSR) and DOE 5480.23 (SAR) Implementation Plans. 
This page is intentionally blank. 
EXECUTIVE SUMMARY

LIST OF TERMS $\mathbf{v}$

1.0 IMPLEMENTATION PLAN SUMMARY $\ldots \ldots \ldots \ldots \ldots \ldots \ldots \ldots \ldots \ldots$

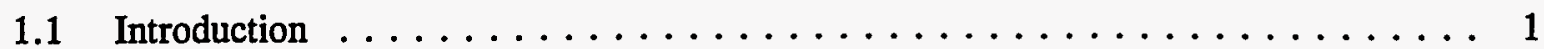

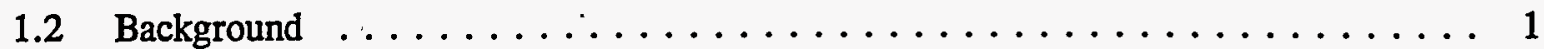

1.3 Summary of Activities on Implementation Plan Since Initial Submittal . . . . . . . 2

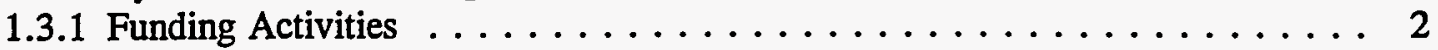

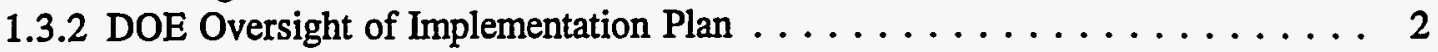

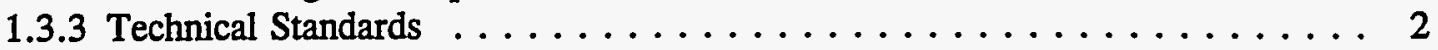

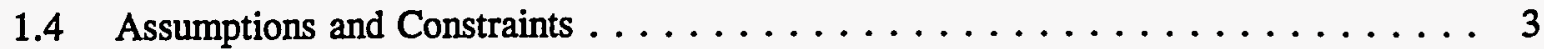

2.0 GENERAL INFORMATION $\ldots \ldots \ldots \ldots \ldots \ldots \ldots \ldots \ldots \ldots \ldots \ldots \ldots \ldots \ldots \ldots$

2.1 Organization of Information in This Plan $\ldots \ldots \ldots \ldots \ldots \ldots \ldots \ldots \ldots$

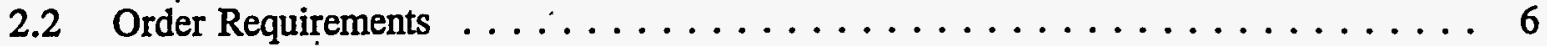

2.2.1 DOE 5480.22, "Technical Safety Requirements" . . . . . . . . . . . . 6

2.2.2 DOE 5480.23, "Nuclear Safety Analysis Reports" . . . . . . . . . . . . . 7

2.3 WHC-managed Nuclear Facilities . . . . . . . . . . . . . . . 8

3.0 APPLICABILITY OF TECHNICAL STANDARDS $\ldots \ldots \ldots \ldots \ldots \ldots \ldots$

3.1 Integration and Application DOE-EM-STD-5502-94 and DOE-STD-1027-92 . . . 10

3.2 DOE-STD-3011-94, Hazard Baseline Documentation . . . . . . . . . . . . . . 10

3.3 DOE-STD-3009-94, Preparation Guide for U.S. DOE Nonreactor Nuclear Facility Safety Analysis Reports

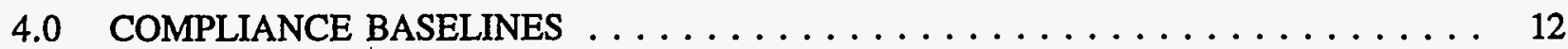

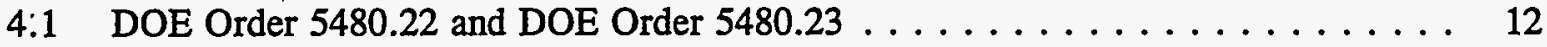

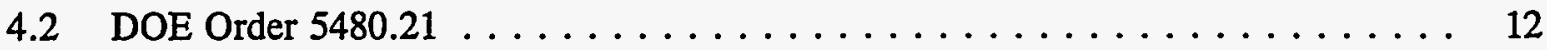

5.0 IMPLEMENTATION STRATEGY AND SAR/TSR UPGRADE PROGRAM $\ldots \ldots \ldots$

5.1 DOE Order Impact Assessment and Implementation Process . . . . . . . . . . . 13

5.2 Strategy for Implementing DOE Orders 5480.22 and $5480.23 \ldots \ldots \ldots \ldots$

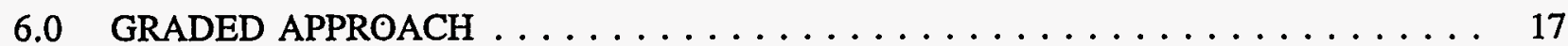

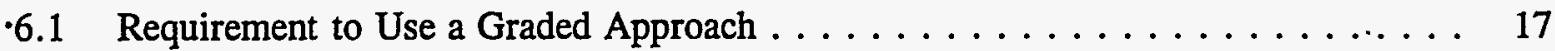

6.2 Key Graded Approach Considerations . . . . . . . . . . . . . . . 18

6.3 Application of the Graded Approach . . . . . . . . . . . . . . . . 19

7.0 RESOURCE ASSESSMENT $\ldots \ldots \ldots \ldots \ldots \ldots \ldots \ldots \ldots$

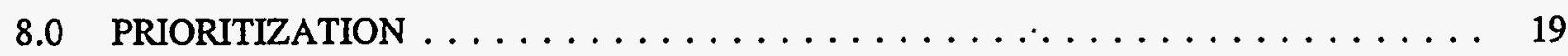

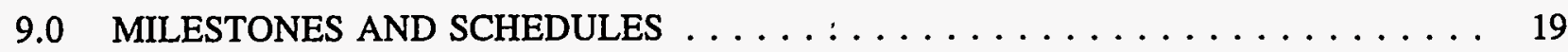

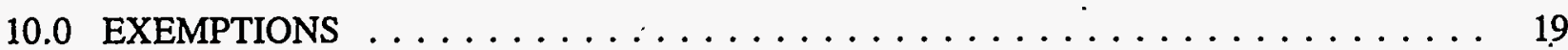

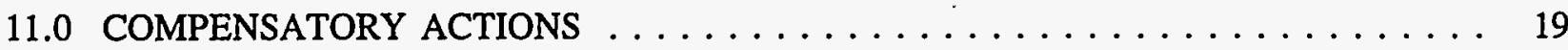


12.0 TRACKING

13.0 REFERENCES *

Appendix A Tank Waste Remediation System (TWRS)

Appendix B Solid Waste Division

Appendix C 340 Facility

Appendix D K Basins

Appendix $\mathrm{E}$ Fuel Supply Shutdown Facility (FSSF)

Appendix $F$ Fast Flux Test Facility (FFTF)

Appendix $\mathbf{G}$ BPlant/Waste Encapsulation Storage Facility (WESF)

Appendix $\mathrm{H}$ Plutonium Finishing Plant (PFP)

Appendix I

Appendix $\mathrm{J}$

Appendix K

Plutonium-Uranium Extraction Facility (PUREX)

308 Building

Appendix L

222-S Laboratory

$\mathrm{UO}_{3}$ Facility 


\title{
LIST OF TERMS
}

\author{
Abbreviations, Acronyms, and Initialisms \\ CAM Continuous Air Monitor \\ CERCLA Comprehensive Environmental Response, Compensation and Liability Act \\ CFR Code of Federal Regulations \\ CH-TRU Contact handled TRU \\ CPC Container Products Corporation \\ CWC Central Waste Complex \\ D\&D Decontamination and Decommissioning \\ DCRT Double-Contained Receiver Tank \\ DMF . Dry Materials Facility \\ DOE U.S. Department of Energy \\ DOE-HQ U.S. Department of Energy - Headquarters \\ DST Double Shell Tank \\ ECN Engineering Change Notice \\ EIS Environmental Impact Statement \\ FFTF Fast Flux Test Facility \\ FSAD Final Safety Analysis Document \\ FSAR Final Safety Analysis Report \\ FY Fiscal Year \\ GDF GROUT Disposal Facility \\ GPF GROUT Processing Facility \\ GTF GROUT Treatment Facility \\ HEPA High Efficiency Particulate Filter \\ HL High Level \\ HPDE High Density Polyethylene \\ IEM Interim Exam and Maintenance \\ IOSR Interim Operational Safety Requirement \\ ISB Interim Safety Basis \\ LCT . Liquid Collection Tank \\ LFMW Low Flash-Point Mixed Waste \\ LL Low Level \\ LLBG Low Level Burial Ground \\ LLW Low Level Waste \\ LWTC . Liquid Waste Tank Car \\ MCS Monitor Control System. \\ MRP Management Requirement and Procedure \\ MP Management Policy \\ MW $\quad$ Mixed Waste \\ NSP · Nuclear Safety Programs \\ ORNL Oak Ridge National Laboratory \\ OSR Operational Safety Requirement
}


Abbreviations, Acronyms, and Initialisms Continued

PFP

Plutonium Finishing Plant

PRC

Plant Review Committee

PRCF

Plutonium Recycle Critical Facility

PRF

Plutonium Reclamation facility

PRTR

Plutonium Recycle Test Reactor

PSAR

Preliminary Safety Analysis Report

PSO

Program Secretarial Officer

PUREX

Plutonium-Uranium Extraction

RCRA

Resource Conservation and Recovery Act

REDOX

RL

Reduction Oxidation (S Plant)

RLWS

RPS

Richland Operations Office

Radioactive Liquid Waste System

SAR

Retention Process Sewer

Safety Analysis and Nuclear Engineering

SNM

Safety Analysis Report

SST

Special Nuclear Material

SWM

TRU

Single Shell Tank

Solid Waste Management

TSD

TSCA

Transuranic

Transuranic Storage and Assay Facility

Technical Support Division

Toxic Substance Control Act

TSR

Technical Safety Requirements

TWRS

Tank Waste Remediation System

$\mathrm{UO}_{3}$

USQ

Uranium Trioxide

WAC

Unreviewed Safety Question

WESF

Washington Administrative Code

WRAP

Waste Encapsulation and Storage Facility

WHC

Waste Receiving and Packaging

Westinghouse Hanford Company

WMU Waste Management Unit 


\subsection{IMPLEMENTATION PLAN SUMMARY}

\subsection{Introduction}

During Fiscal Year 1992, the U.S. Department of Energy, Richland Operations Office (RL) separately transmitted three DOE Orders to Westinghouse Hanford Company (WHC) for compliance. The three Orders are:

- DOE Order 5480.21, "Unreviewed Safety Questions,"

- DOE Order 5480.22, "Technical Safety Requirements," and

- $\quad$ DOE Order 5480.23, "Nuclear Safety Analysis Reports."

WHC has reviewed the Orders and developed a strategy for their implementation in an integrated and disciplined manner. This Implementation Plan (IP) presents the proposed strategy and provides plans for policy-level and facility-specific implementation.

WHC has proceeded with implementation of this plan consistent with DOE approval and funding requests. WHC has completed the implementation of the requirements of DOE Order 5480.21, Unreviewed Safety Questions. The USQ process ensures that each WHC-managed nuclear facility reviews proposed changes and discoveries to the safety basis to determine the approval authority. Reference to the USQ process and requirements throughout this implementation plan are provided for information only and are intended to develop the full scope of the safety basis upgrade and maintenance process.

\subsection{Background}

Table 1.1 identifies the specific dates when the three Orders were issued by the U.S. Department of Energy, Headquarters (DOE-HQ) and the dates when RL transmitted the Orders to WHC for compliance.

Table 1.1 DOE Order Issue and Transmittal Dates

\begin{tabular}{|c|c|c||}
\hline DOE Order & $\begin{array}{c}\text { Date DOE-HQ Issued } \\
\text { the Order }\end{array}$ & $\begin{array}{c}\text { Date RL Transmitted the } \\
\text { Order to WHC for } \\
\text { Compliance }\end{array}$ \\
\hline \hline 5480.21 & $12 / 24 / 91$ & $2 / 12 / 92$ \\
\hline 5480.22 & $2 / 25 / 92$ & $4 / 29 / 92$ \\
\hline 5480.23 & $4 / 30 / 92$ & $8 / 7 / 92$ \\
\hline
\end{tabular}

WHC initiated its DOE Order impact assessment and implementation process upon receipt of the first Order, DOE 5480.21. Before that process was completed, DOE 5480.22 was formally transmitted to WHC for compliance and DOE 5480.23 was circulated for information. A review of the three Orders together revealed they are closely-related and it was concluded that their 
implementation should be accomplished in an integrated manner, rather than separate from each other.

WHC transmitted to RL an initial response to the three Orders on August 19, 1992 and committed to submit a proposed implementation plan by October 28, 1992 (Anderson) which contained the following items:

- an interpretation of the new definition of a Nuclear Facility,

- a list of WHC-managed Nuclear Facilities based on the interpretation, to serve as the baseline set of facilities for the impact assessment and implementation efforts,

- a list of the Safety Basis documents that existed for each Nuclear Facility,

- the results of a WHC policy-level compliance assessment for each of the new Orders which would identify the changes to WHC Level 1 and 2 policy and procedures manuals which are needed, and

- a proposed Implementation Plan addressing the three Orders together, including plans for preparation of facility-specific Interim Safety Basis (ISB) documents, and the cost and schedule impacts for the near-term tasks identified in the plan.

\subsection{Summary of Activities on Implementation Plan Since Initial Submittal}

\subsubsection{Funding Activities}

The change request submitted to support the initial submittal of the Implementation Plan was returned to WHC disapproved (Cameron). WHC-managed nuclear facilities have proceeded with the strategy in the Implementation Plan, by reprioritizing existing workscope and funding identified in their respective Fiscal Year work plans.

\subsubsection{DOE Oversight of Implementation Plan}

DOE audited WHC's implementation of the Implementation Plan in 1994. During the resolution of deficiencies noted in the audit report, WHC and DOE agreed with the strategy outlined in the IP. DOE also agreed that there was no value in upgrading the existing implementation until the corresponding Rules are issued in their final form (Saget).

\subsubsection{Technical Standards}

DOE has issued technical standards to support the preparation of IPs for nuclear safety requirements. The specific standards which provide guidance for preparation of this plan are itemized below:

- DOE-STD-1027-92, Hazard Categorization and Accident Analysis Techniques for Compliance with DOE Order 5480.23, Nuclear Safety Analysis Reports. 
- DOE-STD-1082-94, Preparation, Review, and Approval of Implementation Plans for Nuclear Safety Requirements

- DOE-EM-STD-5502-94, Hazard Baseline Documentation,

- $\quad$ DOE-STD-3009-94, Preparation Guidefor U.S. Department of Energy Nonreactor Nuclear Safety Analysis Reports, and

- DOE-STD-3011-94, Guidance for Preparation of DOE 5480.22 (TSR) and DOE 5480.23 (SAR) Implementation Plans.

Each of the standards above was issued after the initial submittal of this plan. A brief summary and discussion of applicability of the standards relating to the SAR and TSR requirements is addressed in Section 3.0 of this IP.

\subsection{Assumptions and Constraints}

WHC committed to implementing DOE Orders 5480.22 and 5480.23 in a disciplined and integrated manner. In most instances, the Order implementation effort represented additional work scope not included in the work plans. Consequently, formal authorization of additional funding or elimination or deferral of work scope was requested.

This plan served as a tool for communicating to DOE the incremental work scope and requisite funding increase needed to carry out specific actions associated with the proposed implementation strategy. The plan was used in conjunction with a formal change control process to provide the information and authorization vehicle necessary for DOE to direct WHC to proceed with actual implementation.

The implementation tasks addressed in the facility-specific plans were to prepare and submit for approval an Interim Safety Basis document and to establish/revise the Unreviewed Safety Question program at each existing Nuclear Facility to comply with the more rigorous requirements in DOE 5480.21. It should be noted that the costs and durations specified for these tasks did not include the DOE review and approval process for the ISBs, since the turn-around times and resources needed to support the review are uncertain. Recent WHC experience indicated that the DOE SAR review and approval cycle can add at least $50 \%$ to the overall task duration and cost.

The plan also does not address ISB implementation or maintenance costs nor costs and schedules for existing facility SAR upgrade and TSR development efforts, since planning for these significant activities should be contingent on the adequacy of the ISBs themselves. Consequently, plans for these later efforts will be submitted to RL upon issuance of the final Rules. 


\subsection{GENERAL INFORMATION}

This plan is an update to the approved Implementation Plan for DOE Orders 5480.21, 5480.22, and 5480.23 (Saget). The plan has been restructured to meet the guidelines of DOE-STD-1082-94, Preparation, Review, and Approval of Implementation Plans for Nuclear Safety Requirements to facilitate the upgrade of the plan when the corresponding Nuclear Safety Rules are promulgated. The facility-specific sections have been restructured to meet the guidelines of the DOE-STD-3011-94, Guidance for Preparation of DOE 5480.22 (TSR) and DOE 5480.23 (SAR) Implementation Plans.

\subsection{Organization of Information in This Plan}

The information in this document is organized as follows:

\section{Section 1.0 - Implementation Plan Summary}

This summary section is provided for the DOE and reviewers to quickly assess the significant information contained in the plan. This section identifies:

- any requests for exemptions contained in the plan,

- assumptions and constraints, and

- those areas where there is currently full compliance with the requirements.

\section{Section 2.0 - General Information}

This section identifies:

- the DOE Order requirements addressed in the plan,

- revision of the plan and changes since last submittal,

- briefly discusses the format and content of the plan.

Section 3.0-Applicability of Technical Standards

This section identifies the technical standards applicable to the nuclear safety requirements and summarizes the applicability of on a site and facility-specific level.

\section{Section 4.0 - Compliance Baselines}

This section summarizes the extent to which the requirements of the Orders are already met. Reference to the documented assessments is also provided. 
Section 5.0 - Implementation Strategy

This section describes the generic WHC approach to Order implementation and presents the strategy for implementing the DOE $5480.21, .22$, and .23 in an integrated manner. Identical, similar, and logically-related requirements from the Orders are identified and a discussion presented on a logical order for the implementation tasks.

\section{Section 6.0 - Graded Approach}

This section describes the key factors for applying a graded approach on facility-specific basis.

\section{Section 7.0-Resource Assessment}

This section has not been completed at this time. An estimate of the additional life cycle costs to implement the nuclear safety requirements will be provided when the plan is upgraded to the implementation plan required for the Rules.

\section{Section 8.0 - Prioritization}

This section has not been completed at this time. This section will describe the process used to integrate the proposed activities at WHC and each WHC-managed nuclear facility when the plan is upgraded to the implementation plan required for the Rules.

\section{Section 9.0 - Milestones and Schedules}

This section has not been completed at this time. This section will identify the proposed milestones and schedules to implement the nuclear safety requirements when the plan is upgraded to the implementation plan required for the Rules. This section will also identify any impact to activities or commitments outside the scope of the plan and any assumptions ont he availability of resources.

\section{Section 10.0 - Exemptions}

This section has not been completed at this time. This section will identify any exemption requests that are being requested when the plan is upgraded to the implementation plan required for the Rules.

\section{Section 11.0-Compensatory Actions}

This section describes any compensatory actions to be adopted prior to full implementation of the nuclear safety requirements.

\section{Section 12.0 - Tracking}

This section has not been completed at this time. This section will describe the commitment tracking program used at WHC to monitor external commitments. 


\subsection{Order Requirements}

This section summarizes the content of the new DOE Orders and identifies the required deliverables. The summary is intended to quickly familiarize the reader with each Order to lay a foundation for presenting and understanding the integrated implementation strategy and plans presented in this document.

\subsubsection{DOE 5480.22, "Technical Safety Requirements".}

The purpose of DOE 5480.22 is to clearly state the requirements to have Technical Safety Requirements (TSRs) prepared for DOE Nuclear Facilities and to delineate the criteria, content, scope, format, approval process, and reporting requirements of these documents and revisions thereof (DOE 1992b).

According to the Order, TSRs are those requirements which define the conditions, safe boundaries and the management or administrative controls necessary to ensure the safe operation of a Nuclear Facility and to reduce the potential risk to the public and facility worker from uncontrolled release of radioactive materials or from radiation exposures due to inadvertent criticality. TSRs were formerly called Operational Safety Requirements for nonreactor Nuclear Facilities and Technical Specifications for Reactor Facilities.

TSRs are to be based on a facility's Safety Analysis Report. The TSR constitutes an agreement or contract between DOE and the facility operating management regarding the safe operation of the facility. The TSR is to be a controlled document separate from the FSAR.

The implementation tasks and deliverables for the new Order are summarized in Table 2.2.1.

Table 2.2.1 DOE Order 5480.22, "Technical Safety Requirements"

\begin{tabular}{|c|c|c|}
\hline Task or Deliverable & $\begin{array}{l}\text { Requested } \\
\text { Due Date }\end{array}$ & Comments \\
\hline$\frac{\text { New Facilities }}{\text { Submit draft TSR document for approval }}$ & $\begin{array}{l}\text { prior to } \\
\text { operation }\end{array}$ & $\begin{array}{l}\text { "New" defined as a facility which } \\
\text { is scheduled to submit its PSAR or } \\
\text { FSAR to DOE more than } 12 \\
\text { months from the Order issue date }\end{array}$ \\
\hline $\begin{array}{l}\text { Existing Facilities } \\
\text { Review current TS/OSRs and develop plan for converting into } \\
\text { TSR document }\end{array}$ & $8 / 25 / 92$ & \\
\hline $\begin{array}{l}\text { Existing Facilities } \\
\text { Identify and provide "basis for interim operation or restrictions } \\
\text { on interim operations" and administrative controls during } \\
\text { upgrade" }\end{array}$ & $8 / 25 / 92$ & $\begin{array}{l}\text { WHC considers this to be the } \\
\text { "Interim Safety Basis" }\end{array}$ \\
\hline $\begin{array}{l}\text { Existing Facilities } \\
\text { Submit TSR doçument }\end{array}$ & $2 / 25 / 95$ & \\
\hline
\end{tabular}


DOE-HQ issued a temporary exemption from the requirement to submit TSR documents for each nuclear facility by February 25, 1995. The memorandum also clarifies that TSRs must be based on the SAR and recommends that TSR submittal dates be coordinated with and subordinate to upgraded SAR implementation dates (Grumbly 1995).

\subsubsection{DOE 5480.23, "Nuclear Safety Analysis Reports"}

The purpose of DOE 5480.23 is to establish requirements for contractors responsible for the design, construction, operation, decontamination or decommissioning of Nuclear Facilities to develop safety analyses that establish and evaluate the adequacy of the safety bases of the facilities. The Order applies to DOE-owned Nuclear Facilities (DOE 1992a). Non-nuclear facilities are to conduct and document their safety analyses in accordance with DOE 5481.1B.

The Order acknowledges the wide variety of DOE-owned Nuclear Facilities and hazards within those facilities. A graded approach is required to be utilized in the level of analyses and documentation based upon:

- the hazards

- complexity of the operation, and

- $\quad$ stage of facility life-cycle.

The Order also acknowledges a difference between "new" and "existing" facilities. Existing facilities are expected to develop a plan and schedule for upgrading their Safety Basis, as appropriate, over time. The requirement for a SAR upgrade plan indicates that the need for an upgrade should be addressed. It may be appropriate in some cases, based on the adequacy of the existing Safety Basis documentation and the facility life cycle, to request an exemption to the requirement to upgrade a facility's SAR. New facilities (those scheduled to submit a PSAR or FSAR to DOE more than 12 months after Order issuance ) are expected to comply with the new Order requirements.

The implementation tasks and deliverables for the new Order are summarized in Table 2.2.2. 
Table 2.2.2 DOE 5480.23, "Nuclear Safety Analysis Reports"

\begin{tabular}{|c|c|c|}
\hline के Task or Deliverable & Requested & 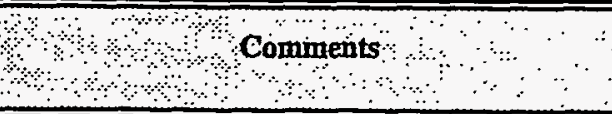 \\
\hline $\begin{array}{l}\text { New Facilities } \\
\text { Submit compliant PSAR and FSAR }\end{array}$ & $\begin{array}{l}\text { prior to } \\
\text { construction and/or } \\
\text { operation }\end{array}$ & $\begin{array}{l}\text { "New" defined as a facility which is scheduled } \\
\text { to submit its PSAR or FSAR to DOE more } \\
\text { than } 12 \text { months from the Order issue date }\end{array}$ \\
\hline $\begin{array}{l}\text { Existing Facilities } \\
\text { Submit plan and schedule for SAR } \\
\text { upgrade addressing the following: } \\
\text { - } \quad \text { Need for upgrade } \\
\text { Preliminary assessment of } \\
\text { hazards } \\
\text { Basis for interim operation or } \\
\text { restrictions and administrative } \\
\text { controls }\end{array}$ & $\begin{array}{l}{[10 / 30 / 92]} \\
\text { twelve months } \\
\text { after Order } \\
\text { issuance }\end{array}$ & $\begin{array}{l}\text { WHC plans to address bullet items in an } \\
\text { "Interim Safety Basis" document. } \\
\text { Order requires DOE PSO approval of plan. } \\
\text { Contractor to consider plan approved if no } \\
\text { comments are received from PSO within } 180 \\
\text { days, however, WHC cannot proceed with } \\
\text { approved plan without DOE authorization of } \\
\text { requisite funding. }\end{array}$ \\
\hline
\end{tabular}

The program secretarial officer delegated the review and approval authority for certain types of safety documentation specified in DOE Order 5480.23. The delegation included safety analysis reports, technical safety requirements, unreviewed safety questions, safety evaluation reports, and criticality safety evaluations (Grumbly 1994).

\subsection{WHC-managed Nuclear Facilities}

Title 10 of the Code of Federal Regulations (CFR) Part 830.3, Definitions, defines a nonreactor nuclear facility as those activities or operations that involve radioactive and/or fissionable materials in such form and quantity that a nuclear hazard potentially exists to the employees or the general public. Incidental use and generating of radioactive materials in a facility operation (e.g., check and calibration sources, use of radioactive sources in research and experimental and analytical laboratory activities, electron microscopes, and X-ray machines) would not ordinarily require the facility to be included in this definition. Transportation of radioactive materials, accelerators and reactors and their operations are not included. The application of any rule to a nonreactor nuclear facility shall be applied using a graded approach. Included are activities or operations that:

(1) Produce, process, or store radioactive liquid or solid waste, fissionable materials, or tritium;

(2) Conduct separations operations;

(3) Conduct irradiated materials inspection, fuel fabrication, decontamination, or recovery operations;

(4) Conduct fuel enrichment operations;

(5) Perform environmental remediation or waste management activities involving radioactive materials; or

(6) Design, manufacture, or assemble items for use with radioactive materials and/or fissionable materials in such form or quantity that a nuclear hazard potentially exists. 
The list of WHC-managed nuclear facilities which includes those activities that involve radioactive and/or fissionable materials in such form and quantity that a nuclear hazard potentially exists to employees or the general public is detailed below.

Tank Farms

242-A Evaporator

242-S Evaporator

242-T Evaporator

Waste Tanks (Aging Waste, Double Shell, and Single Shell)

GROUT

Solid Waste Division

Central Waste Complex

Burial Grounds

Transuranic Storage and Assay Facility (TRUSAF)

T Plant

340 Waste Handling Facility

K Basin Facility

N Reactor Fuel Supply Facility

Fast Flux Test Facility (FFTF)

B-Plant

Waste Encapsulation Storage Facility (WESF)

Plutonium Finishing Plant (PFP)

Plutonium Uranium Extraction (PUREX) Facility

$\mathrm{UO}_{3}$ Facility

222 S Laboratory

308 Building

The list of WHC-managed nuclear facilities was determined in accordance with the criteria of DOE-STD-1027-92, Hazard Categorization and Accident Analysis Techniques for Compliance with DOE Order 5480.23, Nuclear Safety Analysis Reports, and DOE-EM-STD-5502-94, Hazard Baseline Documentation. Section 3.1.1 details the WHC process, integration, and application of these two standards.

The list of WHC-managed nuclear facilities is a living document and is updated as needed (e.g., radioactive inventory is removed from a facility). WHC submits the list of nuclear facilities to $\mathrm{RL}$ on November $1^{\text {st }}$ of each year. 


\subsection{APPLICABILITY OF TECENICAL STANDARDS}

DOE has issued several standards since.the initial release of the plan:

- DOE-STD-1027-92, Hazard Categorization and Accident Analysis Techniques for Compliance with DOE Order 5480.23, Nuclear Safety Analysis Reports.

- DOE-EM-STD-5502-94, Hazard Baseline Documentation,

- $\quad$ DOE-STD-3009-94, Preparation Guide for U.S. Department of Energy Nonreactor Nuclear Safety Analysis Reports, and

- DOE-STD-3011-94, Guidance for Preparation of DOE 5480.22 (TSR) and DOE 5480.23 (SAR) Implementation Plans.

This section addresses the applicability, integration, and implementation of each Standard.

\subsection{Integration and Application DOE-EM-STD-5502-94 and DOE-STD-1027-92}

These standards provide guidance for determining the appropriate hazard baseline documentation for a facility based on the type and level of hazards that it contains, for integrating and controlling the safety documentation, and for establishing a facility classification of nuclear, radiological, nonnuclear, or other industrial.

Facilities that contain releasable radiological inventories above the Category 3 threshold of DOE-STD-1027-92 are considered to be nuclear facilities, with DOE 5480.21, 5480.22, and 5480.23 applicable. This is implemented in WHC-CM-4-46, Safety Analysis Manual, Chapter 4.0, Hazard Categorization.

Facilities that contain releasable radiological inventories below the Category 3 threshold are considered to be radiological, non-nuclear, or other industrial in accordance with the thresholds of DOE-EM-STD-5502-94. The draft revision of WHC-CM-4-46, Chapter 2.0, Safety Analysis Process (release scheduled for September 30, 1995) contains guidance for:

- $\quad$ preparation and integration of the facility safety analysis (DOE 5481.1B, Safety Analysis and Review System), and other hazard baseline documentation,

- application of process safety management principles, and

- control of the authorization basis for radiological and non-nuclear facilities.

\subsection{DOE-STD-3011-94, Hazard Baseline Documentation}

This standard provides additional guidance for the preparation of the implementation plan for DOE Order 5480.22 and DOE Order 5480.23. The TSR and SAR IP serves as the transition plan for achieving compliance with nuclear safety requirements.

WHC initially outlined the implementation strategy for the DOE Order 5480.23 (SAR) and DOE Order 5480.22 (TSR) in October 1992. The implementation requirements specified in the Orders required the identification of interim restrictions and operating controls for each WHC-managed 
nuclear facility to form the basis for the upgrade program. WHC specified the minimum format and content requirements for the facility's interim safety basis in WHC-CM-4-46, Safety Analysis Manual, Section 8.0, Interim Safety Basis.

The ISBs prepared to date do not meet the full intent of DOE-STD-3011-94. WHC will not upgrade the ISBs prepared for each WHC-managed facility. The Standard will not be applied to existing documentation prepared to date unless requested and funded by the responsible program office within RL.

\subsection{DOE-STD-3009-94, Preparation Guide for U.S. DOE Nonreactor Nuclear Facility Safety} Analysis Reports

This Standard describes a SAR preparation method that is acceptable to the DOE. It was developed to assist facilities in preparing SARs that will satisfy the requirements of DOE Order 5480.23. The application and implementation of this standard are described in WHC-CM-4-46, Chapter 2.0 (revision), and will be defined on a facility-specific basis in their specific sections of this plan. 


\subsection{COMPLIANCE BASELINES}

\subsection{DOE Order 5480.22 and DOE Order 5480.23}

A WHC Level 1 and 2 policy-level compliance assessment for DOE Order 5480.23 was completed and the results are maintained on file within Nuclear Safety Programs (NSP).

The safety analysis process, SAR content requirements, and TSR format and content requirements for nonreactor facilities are clearly defined in the WHC-CM-4-46, Nonreactor Facility Safety Analysis Manual. The requirements in this manual are specific and implement the mandatory requirements of DOE Orders 5480.22 and 5480.23. Revisions to WHC-CM-4-46 and other manuals have been identified to provide clarification and additional guidance for some Order and Standard requirements.

\subsection{DOE Order $\mathbf{5 4 8 0 . 2 1}$}

The WHC process requirements for Unreviewed Safety Questions (USQ) has been in WHC-CM-1-3, MRP 5.12, Identifying and Resolving Unreviewed Safety Questions. These requirements are being modified to incorporate lessons learned from implementation experience and subsequent site-wide assessments. The requirements will also be moved to another manual, WHC-CM-1-5, Standard Operating Practices. 


\subsection{IMPLEMENTATION STRATEGY AND SAR/TSR UPGRADE PROGRAM}

This section describes the generic WHC process for implementing new and revised DOE Orders and presents the proposed strategy for implementing DOE Orders 5480.21, .22, and .23.

\subsection{DOE Order Impact Assessment and Implementation Process}

This subsection describes the basic DOE Order impact assessment and implementation process utilized by WHC. DOE Orders are transmitted to WHC for compliance by an RL contracting officer or designee. Upon receipt of a new or revised Order, WHC initiates the process depicted in Figure 5.1.

WHC Contracts Administration assigns the Order to the appropriate WHC organization responsible for coordinating the impact assessment and implementation plan development. Since DOE Orders typically apply to multiple WHC-managed facilities, the affected facility management and support staff are directly involved in assessing impacts and developing facility-specific implementation plans. Upon completion, the facility-specific assessments and implementation plans are consolidated for transmittal to $\mathrm{RL}$ via WHC Contracts Administration.

When the Orders necessitate a change in work scope and additional resources would be required to carry out their implementation, the formal change request process is utilized to obtain DOE authorization. WHC proceeds with implementation upon receipt of DOE approval of the implementation plan and any requisite change requests.

\subsection{Strategy for Implementing DOE Orders 5480.22 and 5480.23}

As indicated in Section 1.0, Table 1.1, RL separately transmitted DOE Orders 5480.21, 5480.22, and 5480.23 to WHC for compliance in February, April, and August of 1992, respectively. The responsibility for coordinating the WHC preparation of impact assessments and implementation plans was assigned to Nuclear Safety Programs (NSP).

NSP performed an initial review of each Order and identified several key requirements and implementation deliverables in the Orders which were either identical, similar, or logically interrelated. NSP and affected facility management developed an integrated implementation strategy to address the three Orders together, rather than addressing each Order in isolation from the others. This basic strategy was summarized and communicated to RL in August 1992 (Anderson). WHC has since proceeded to develop policy-level and facility-specific implementation plans for the near-term tasks, in accordance with the strategy. 
Figure 5.1 Generic Order Implementation Strategy 
The strategy is comprised of three primary objectives, as follows:

1) Obtain DOE approval of a single list of DOE-owned and WHC-managed Nuclear Facilities,

2) Establish and/or upgrade the "Safety Basis" for each Nuclear Facility, and

3) Establish a functional Unreviewed Safety Question (USQ) process to govern the management and preservation of the Safety Basis for each Nuclear Facility.

Objective 1 is appropriate because the three new Orders apply only to Nuclear Facilities; the definition of a Nuclear Facility was changed in the new Orders, and a single Nuclear Facility list with joint DOE and WHC concurrence does not exist. Objective 2 reflects the basic intent of DOE Orders 5480.22 and .23 regarding Technical Safety Requirements and Safety Analysis Reports. Finally, Objective 3 reflects the basic intent of DOE Order 5480.21.

Figure 5.2 depicts the logical relationship between Objectives 2 and 3. As shown, and as acknowledged in DOE Order 5480.21, Objective 2 is a prerequisite to accomplishing Objective 3 in that a "Safety Basis" must be defined as part of establishing a functional USQ process. 
Figure 5.2 Integrated Implementation Strategy 


\subsection{GRADED APPROACH}

\subsection{Requirement to Use a Graded Approach}

The complete set of activities necessary to meet the nuclear safety requirements, as well as the level of depth, rigor, and thoroughness in applying them to each WHC-managed nuclear facility are determined by applying a graded approach.

DOE Orders 5480.22 and 5480.23 require a graded approach to the development of the safety basis documentation. The Orders acknowledge the wide variety of DOE-owned Nuclear Facilities and hazards within those facilities. A graded approach is required to be utilized in the level of analyses and documentation based upon:

- the hazards,

- complexity of the operation, and

- $\quad$ stage of facility life-cycle.

Title 10 CFR Part 830.3 defines a graded approach as a process by which the level of analysis, documentation, and actions necessary to comply with a requirement in this Part are commensurate with:

\footnotetext{
- The relative importance to safety, safeguards, and security, .

- The magnitude of any hazard involved,

- The life cycle stage of a facility,

- The programmatic mission of a facility,

- The particular characteristics.of a facility, and

- Any other relevant factor.
}

The graded approach concept may be applied to a number of areas, including implementation of safety upgrades and modifications, performance of safety analyses, level of safety documentation, compliance issues in general, training, and the number and rigor of appraisais, assessments and reviews. Recognizing that there are varied applications and numerous considerations, it is recommended that procedures developed to implement graded approach reflect simplicity, flexibility and deal in principals as opposed to being a highly prescriptive and quantified process. A rigid process could not lend itself from a practical standpoint to all the varied facilities and conditions on the Hanford Site.

The principals (key considerations), described below, will be applied on a case-by-case basis and the conclusions justified and documented. Experience with other far-reaching processes on the Hanford Site, confirm that procedural simplicity and good examples are needed for effective implementation. In keeping with the above recommendations, it is possible to package subsets of the key considerations for different areas of application. For example, training adequacy, the number of reportable and recurring events, and general operating performance are important to implementing graded approach for appraisals and assessments, but are not relevant to using graded approach in the preparation of safety analysis reports. 


\subsection{Key Graded Approach Considerations}

Many of the WHC documents use the receiver of the potential consequences (i.e., the offsite public, the onsite or co-located worker, and the facility worker) as a discriminating factor for implementing graded approach. This factor has a historical basis both in the commercial nuclear power industry and in the DOE complex. In addition, the magnitude of the inherent hazard(s) of a facility or activity are frequently used, and these two considerations (receiver and hazard) are often coupled. In more recent documents, the potential for environmental impact, with emphasis outside the Federal reservation, is a graded approach consideration. And, in terms of backfits and safety upgrades, the degree of risk reduction or benefit gained has always been a consideration, although not called "graded approach". Below is a list of considerations, including the above, which should form part of a graded approach process. These considerations may be quantified in some cases, include a risk determination, placed in a matrix format and/or customized for different areas of application.

- Facility/activity potential consequence (risk) to the offsite public, onsite (co-located) worker, or facility worker.

- Facility/activity potential consequence (risk) to the environment, both onsite and offsite.

- Activity/process potential consequence (risk) to a facility's mission or the Hanford Site mission.

- Importance of a facility's mission/activity to national security.

- Importance of a facility's mission/activity to DOE goals.

- Importance of a system/activity to safeguards and/or security.

- Inherent hazard(s) of a facility or activity.

- Status of the facility in its life cycle and the relevancy of issues in consideration of the remaining operational lifetime.

- Incremental increase in public or worker safety, environmental protection, mission success, accomplishment of goal(s) by utilizing more stringent requirements or instituting upgrades.

- $\quad$ Cost benefit (preferably life-cycle cost).

- Most advantageous risk reduction measure.

- Complexity of the facility/system(s)/component(s).

- Added complexity due to upgrade/modification.

- Degree of personnel action as opposed to automated action to perform a safety function(s).

- Operational characteristics, i.e., operating, shutdown, cold standby, etc.

- Available alternatives that may satisfy the intent of a requirement or objective.

- Performance-based observations, e.g., operational experience, existing maintenance and upgrade programs, appraisal history, regulatory compliance history, etc.

- Relevance of activity to violating Federal or Washington State laws, agreements or regulations and their relationship to enforcement fines or criminal penalties.

- The uniqueness, cost or replaceability of an item or the uniqueness of an activity.

DOE-STD-1027-92 provides additional guidance on the application of the graded approach for hazards analysis. DOE-STD-3009-94 provides additional guidance on the application of the graded approach for the Final SAR. 


\subsection{Application of the Graded Approach}

The graded approach will be applied on a facility-by-facility basis using the guidance outlined above. The basis for the graded approach will be documented in the facility-specific plans in accordance with 10 CFR 830.7, Graded Approach, when the plan is upgraded for the Rules.

\subsection{RESOURCE ASSESSMENT}

To be determined. This section will be completed when this IP is upgraded for the Rules.

\subsection{PRIORITIZATION}

To be determined. This section will be completed when this IP is upgraded for the Rules.

\subsection{MILESTONES AND SCHEDULES}

To be determined. This section will be completed when this IP is upgraded for the Rules.

\subsection{EXEMPTIONS}

To be determined. This section will be completed when this IP is upgraded for the Rules.

\subsection{COMPENSATORY ACTIONS}

Compensatory actions to ensure the safety of the general public and workers during the upgrade of the safety basis documentation are addressed in each facility-specific section as appropriate.

\subsection{TRACKING}

To be determined. This section will be completed when this IP is upgraded for the Rules. 


\subsection{REFERENCES}

Anderson, T. M. Anderson to J. D. Wagoner, "DOE ORDERS 5480.21, 5480.22, AND 5480.23," Letter, dated August 19, 1992.

Cameron, K. D. to President, WHC, "Return Without Approval of Change Request BI-93-003 Implementation Plan for New Orders," Letter, dated February 11, 1993.

DOE 1991, "Unreviewed Safety Questions", DOE Order 5480.21, U.S. Department of Energy.

DOE 1992a, "Nuclear Safety Analysis Reports", DOE Order 5480.23, U.S. Department of Energy.

DOE 1992b, "Technical Safety Requirement", DOE Order 5480.22, U.S. Department of Energy.

Gallagher, J. L. to T. M. Anderson et. al., "Risk Acceptance Guidelines", Letter, December 11, 1991.

Grumbly, T. P. to Secretary of Energy, "Temporary Exemption for Submittal as Required by Department of Energy Order 5480.22 for Offices of Defense Programs, Environmental Management, and Energy Research Nuclear Facilities," Memorandum, dated February 24, 1995.

Grumbly, T. P. to EM Deputy Assistant Secretaries and Operations and Field Office Managers, "Delegation of Review and Approval Authority for Safety Documentation and for Startup/Restart for Environmental Management Field Activities," Memorandum, dated August 9. 1994.

Hapke, P. L. to T. K. Teynor, "Central Waste Complex Interim Safety Basis," Letter, dated June 8, 1995.

Holten, R. A. to T. M. Anderson, "Standardization of the Administrative Section of Technical Safety Requirements (TSRs)," Letter, dated August 28, 1992.

Saget, R. P. to A. L. Trego, "Acceptance of Response to Audit of Nuclear Safety Order. Implementation," Letter, August 16, 1994.

Schwallie, A. L. to R. T. Bell, "Price Anderson Amendment Act", Letter, March 24, 1992.

Teynor, T. K. to A. L. Trego, "Approval of the 340 Waste Handling Facility Interim Safety Basis," Letter, June 9, 1995.

Wagoner, J. D. to T. M. Anderson, "Approval of Hanford Site Tank Farm Facilities Interim Safety Basis," Letter, November 18, 1993.

Wagoner, J. D. to A. L. Trego, "Approval of Hanford PUREX Authorization Basis for Deactivation," Letter, March 2, 1994.

Wagoner, J. D. to A. L. Trego, "Revision of Hanford PUREX Authorization Basis for Deactivation," Letter, August 5, 1994. 
Wagoner, J. D. to A. L. Trego, "Approval of Interim Safety Basis (ISB), Interim Safety Analysis (ISA), and Interim Operational Safety. Requirements (IOSR), and Issuance of the Safety Evaluation Report (SER) for the Solid Waste Burial Grounds," Letter, dated August 18, 1995.

WHC 1992a, Nonreactor Facility Safety Analysis Manual, WHC-CM-4-46, Westinghouse Hanford Company, Richland, WA.

WHC 1992b, "Radiological Release Assessment for the 308 Building," WHC-SP-0796, Westinghouse Hanford Company, Richland, WA.

Wiborg, J. C. Wiborg to R. A. Holten, "Contractor Annual Submittal of List Identifying Nuclear Facilities," Letter, dated November 1, 1991 
WHC-SP-1164

Appendix A

Approval Signatures

he for

$9 / 28 / 95$

W. E. Ross, Facility Manager

Date

$\therefore$

$y$ 


\section{A.1 Mission}

The mission of the Tank Waste Remediation System (TWRS) is to store, treat, and immobilize highly radioactive waste in an environmentally sound, safety, and cost effective manner.

\section{A.2 Nuclear Facilities}

The Tank Waste Remediation System contains several nonreactor nuclear facilities. TWRS nonreactor nuclear facilities include Waste Tanks (i.e., Single Shell Tank Farms, Double Shell Tank Farms, and Aging Waste Tank Farm), 242-A Evaporator, 242-S Evaporator, 242-T Evaporator, and Grout.

\section{A.3 Description and Status of TWRS Nonreactor Nuclear Facilities}

\section{A.3.1 Waste Tanks}

The Waste Tanks consist of underground tanks that store highly radioactive mixed waste. The waste tanks (both single and double shell) are located in the tank farms located in the 200 East and 200 West Areas of the Hanford Site.

The Single Shell Tanks have one carbon steel wall, are surrounded by reinforced concrete, and are situated below ground level. They were constructed between the years 1944 and 1964, and accepted waste until 1980. Waste in the Single Shell Tanks consists of liquids, sludges, and saltcake. Over the years the majority of the free-standing liquids have been transferred to Double Shell Tanks.

The Single Shell Tanks and ancillary structures are aged plants in a less-than-desirable material condition. About one-half of the Single Shell Tanks have leaked, or are assumed to have leaked. Most of the systems, components and structures have exceeded their design life. The Single Shell Tanks have been physically isolated and are no longer capable of accepting waste.

The objective for the TWRS organization is to achieve a safe, stable, and shutdown mode for the Single Shell Tanks. Therefore those activities which are applicable to operations will be curtailed as the Single Shell Tanks progress to the shutdown mode. Action Items 1, 2, 4, and 5 do not apply to Single Shell Tanks.

Double Shell Tanks, which have two carbon steel walls, were constructed between the years 1970 and 1986, and were designed for 50 years of storage. The space between the two walls is monitored for leaks. None of the Double Shell Tanks have been known to leak. The Double Shell Tanks are used to treat and store a variety of liquid radioactive wastes from the Double Shell Tanks and from various Hanford Site processes. The wastes are stored in tanks based upon their composition, level of radioactivity, or origin. Waste transfers routinely occur between Double Shell Tanks as part of the active waste management practices required for the continued safe storage of the wastes. 


\section{2-A Evaporator-Crystallizer}

The 242-A Evaporator is operational and is employed to reduce the volume of Double Shell Tank waste contents. A recently completed facility upgrade has extended the design life into the early $21^{\text {st }}$ century and has also brought important portions of the facility up to current design and safety standards. Several operational campaigns are currently planned to reduce the volume of wastes stored in the tank farms.

\section{2-S,T Evaporators}

242-S, T Evaporators are no longer operable, and are in a shutdown/standby mode. However, these two facilities have their own safety basis documentation and as such are individual nuclear facilities.

\section{Grout}

The Grout Treatment Facility is a low-level waste nonreactor nuclear facility which combines cementitious materials with low-level radioactive liquid waste for permanent disposal. It consists of a nonradioactive dry component storage and mixing plant, a dry component-waste mixing facility, and below-grade disposal vaults for the resultant grout.

As a result of the recent Tank Waste Remediation System rebaselining activity, the Grout Treatment Facility was shut down and placed in standby. Current standby plans will allow for a facility restart within two years if emergency tank space is needed. Prior to rebaselining, one below-grade disposal vault was filled with nonhazardous, low-activity grout during August 1988 startup, and sealed for interim stabilization until final site closure.

\section{A.4 Need for Upgrade}

This section is incomplete at this time. This section will be upgraded to provide a discussion of the extent to which the safety documentation does or does not meet the requirements of the Final Rules for each nuclear facility in TWRS when this IP is upgraded to be the Rule Implementation plan. 


\section{A.5 Summary of the Technical Standards}

This section is incomplete at this time. This section will be upgraded to identify the applicability of the DOE technical standards identified in section 3.1 of this plan for each TWRS nuclear facility when this IP is upgraded to be the Rule Implementation Plan.

\section{A.6 Basis for Interim Operations}

The Tank Farm DOE Order Implementation Plan addressed the following Tank Farm Facilities:

- Waste Tanks (SST, DST, and AW)

(this includes the 204-AR and 244-AR ancillary facilities)

- 242-A Evaporator

- 242-S, T Evaporators

- Grout

Progress has been achieved in the implementation plan. In addition to the Tank Farm Facilities addressed in the Implementation Plan, other tank farm facility projects and upgrades are planned which will be addressed in appropriate authorization basis documents. The following provides a brief status of the Implementation Plan for the above noted Tank Farm Facilities, and planned facility projects and upgrades.

\section{A.6.1 Waste Tanks}

The Hanford Site Tank Farm Facilities Interim Safety. Basis (ISB) was developed as committed and issued in July of 1993. DOE approved Chapter 6 and associated safety bases documentation referenced therein as the "authorization basis" for Tank Farms in accordance with DOE Order 5480.21 for the purposes of Unreviewed Safety Question (USQ) determinations, resolving USQ program issues and authorizing new and emerging activities (Wagoner). The Tank Farms ISB has been updated periodically with an annual update submitted to DOE as recently as July $28,1995$.

\section{A.6.2 242-A Evaporator}

The Safety Basis for the 242-A Evaporator remains as WHC-SD-WM-SAR-023. Revision 2 to the Evaporator Safety Analysis Report is an annual update to the SAR which has been submitted to DOE for review and approval. There are no present plans to issue an ISB for the 242-A evaporator.

\section{A.6.3 242-S, T Evaporators}

Both of these facilities are no longer operational. The current safety bases for these facilities are WHC-SD-HS-SAR-009, Rev 0, "242-T Evaporator Shutdown/Standby Safety Analysis Report," and WHC-SD-SSP-002, Rev 0, "242-S Facility Shutdown/Standby Plan," as noted in the WHC DOE Order Implementation Plan. USQs for changes to these facilities continue to be conducted using the aforementioned authorization bases. 


\section{A.6.4 Grout}

The following documents define the SAFETY BASIS for Grout:

- WHC-SD-WM-SAR-027, "Hazards Identification and Evaluation Report for the Operation of the Grout Facilities, and Near Surface Disposal of Grouted Phosphate/Surface Low Level Liquid Waste"

- WHC-SD-WM-SAR-042, "Grout Final Safety Analysis Report"

\section{A.7 Plan and Schedule}

This section will provide the plan and schedule to develop the upgraded safety analysis for each nonreactor nuclear facility in TWRS when this plan is upgraded to be the Rule Implementation Plan. 


\section{Approval Signatures}
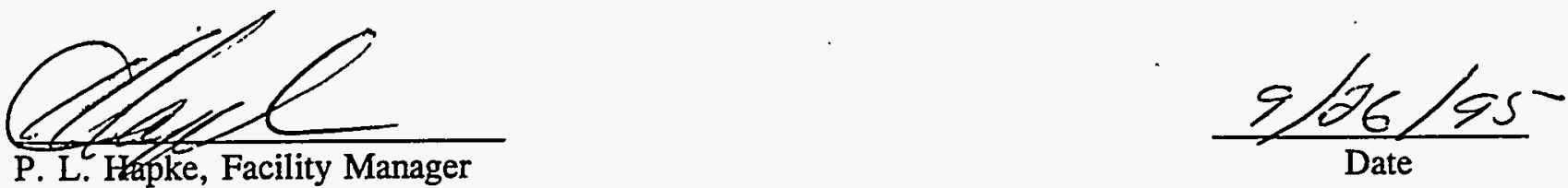

Central Waste Complex, Solid Waste Burial Grounds, and TRUSAF

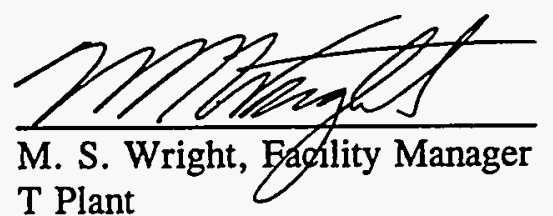

$9 / 26 / 55$

Date

\section{T Plant}




\section{B.1 Mission}

The Solid Waste Operations Complex (SWOC) receives, stores, treats, decontaminates, and disposes of solid radioactive and nonradioactive dangerous wastes in a safe, cost effective, and environmentally compliant manner.

\section{B.2 Nuclear Facilities}

The SWOC contains several nonreactor nuclear facilities; the Central Waste Complex (CWC), Solid Waste Burial Grounds, Transuranic Storage and Assay Facility (TRUSAF), and T Plant.

\section{B.3 Description of SWOC Nonreactor Nuclear Facilities}

\section{B.3.1 Central Waste Complex}

The CWC is a multi-facility complex, located in the 200 West Area of the Hanford Site. The CWC receives and stores most of the solid mixed wastes (MW) that are generated, received, and stored at the Hanford Site. The solid wastes that are handled at the CWC include both currently stored and newly generated contact-handled transuranic (CH-TRU), low level waste (LLW), MW, and transuranic (TRU)/PCB wastes.

The CWC is comprised of approximately 17 storage buildings, 25 low-flashpoint modules, 12 alkali metal storage modules, 2 pads, and support facilities. The CWC provides storage space for approximately 55,400 208-L (55 gal) or equivalent waste containers. Facilities with physical features that provide for segregated storage areas are operated to maintain appropriate separation between arrays of incompatible waste.

The Plutonium/Polychlorinated Biphenyl Storage Facility (2401-W) was designed to meet all the requirements for $\mathrm{PCB}$, hazardous, radioactive, or mixed type wastes. The storage facility is a preengineered steel structure $50 \mathrm{ft}$ wide by $80 \mathrm{ft}$ long with a clear span in the $50 \mathrm{ft}$ direction and an eave height of $20 \mathrm{ft}$. The 26-gauge metal structure has high rollup truck doors and 2 personnel doors. The foundation is integrated into a perimeter concrete curb 6 in. above grade. A ramp is provided to cross the curb at the truck door.

The Low Flashpoint Mixed Waste (LFMW) and alkali metal waste (AMW) Storage Modules are designed to meet storage requirements for hazardous and radioactive (except flammable TRU) wastes. Two of the modules have been modified for TRU flammable waste. The modules are small pre-engineered buildings. The front, back and side walls of all of the modules are constructed of 10-gauge steel coated with chemical-resistant epoxy paint inside or have a corrosion resistant covering. All the roofs are constructed of 12-gauge steel. Modules 1, 2, and 3 have fire-retardant plywood floors and ceilings within the metal skin. All modules have a 4 in. deep vented catch sump under the storage floor which provides spill containment and precludes spills from affecting other containers by keeping the storage deck clean.

The Mixed Waste (MW) Storage Facility consists of an initial phase consisting of 12 identical storage buildings (2402-W and 2402-WB through 2402-WL). Adjacent to the buildings are two open air pads: an asphalt staging area and a concrete storage pad. The buildings were designed to meet the requirements for hazardous, mixed, and radioactive wastes. The storage buildings are 
each $4,000 \mathrm{ft}^{2}$ metal structures, approximately $50 \mathrm{ft}$ wide by $80 \mathrm{ft}$ long with a minimum clear span of $1240 \mathrm{ft}$ and an eave height of approximately $20 \mathrm{ft}$.

The Waste Receiving and Staging Area is an asphalt pad approximately $200 \mathrm{ft}$ long and $150 \mathrm{ft}$ deep. The pad is used for handling and staging containers of radioactively contaminated waste destined for the various facilities. Components of the pad include an access for loaded trucks and other vehicles.

The MW Storage Pad is a 6 in. curbed 9,000 $\mathrm{ft}^{2}$ concrete pad with an access ramp. The pad has a rainwater collection and removal system.

The latest phase of the MW Storage Facility consists of four large buildings (2403-WA through 2403-WD). Each storage building is planned and designed to contain four separate quadrants for managing various waste categories. Each building was designed to meet all the requirements for hazardous, mixed, and radioactive type wastes. Only compatible wastes will occupy any one zone at any one time.

Each building is steel-supported, sheet metal-covered structure with unobstructed clear height of no less than $17 \mathrm{ft}$ and roof slopes of 1 in 12 . The structural system is modular beam and column rigid frame. Each rigid frame is supported by two interior columns, spaced at distances of onethird of the building's overall width. The roof and wall panels are 26-gauge steel sheets with exterior finish.

Each building is un-insulated with the exception of the heated sprinkler riser enclosure. The purpose of the enclosure is to provide a heated space within which the sprinkler system riser may be housed and kept from freezing.

\section{B.3.2 Solid Waste Burial Grounds}

The LLBG are located in the 200 East and 200 West Areas of the Hanford Site. The LLBG are classified as a landfill and cover a total area of approximately 518 acres. The landfill is divided into eight burial grounds. Each burial ground is comprised of a number of trenches. Six burial grounds are located in the 200 West Area and two burial grounds are located in the 200 East Area.

The burial grounds consist of trenches that are linearly oriented excavations used for a variety of waste that have included, but not limited to, low-level waste in sealed fiberboard boxes, 55-gallon, drums, specially fabricated wood, metal, and reinforced concrete containers and both packaged and direct-buried failed equipment.

Prior to April, 1970, all solid wastes, regardless of radionuclide content, were placed in trenches and covered with earth to prevent release of contamination. Since then, DOE required that radioactive solid wastes be segregated by categorizing as either transuranic (TRU) and placed in retrievable storage or non-TRU and placed in non-retrievable disposal sites. In 1985, steel drums of radioactive mixed waste were placed in retrievable storage trenches. In 1987, the mixed waste burial was halted with the exception of the disposal of mixed waste containers with a dose rate greater than 200 millirem per hour at the container surface and special-case wastes such as Navy nuclear submarine reactor compartments. 


\section{B.3.3 TRUSAF}

The TRUSAF Facility (224-T) is located in the 200 West Area of the Hanford Site.

The 224-T Building was originally constructed for purifying plutonium. It was idle for several years after new processes made it obsolete. The 224-T Building was modified to meet requirements for the storage of plutonium bearing scrap and liquids. The cells in the processing areas have been completely sealed and isolated from the operating gallery and service areas. These operating and services areas have been stripped of all unnecessary control equipment, panel boards, and partitions to provide approximately $11,500 \mathrm{ft}^{2}$ of storage space on three floors.

The 224-T Building is approximately $197 \mathrm{ft}$ long and $60 \mathrm{ft}$ wide. The modified building is constructed of reinforced concrete walls, floor, and ceiling.

The three floors of the building used for TRUSAF are completely sealed from the southeast third of the building which contains the six contaminated process cells. The floors are connected by stairway A at the north end of the building, by stairway B at the south end of the building, and by an elevator adjacent to stairway $A$. There is also an unloading platform off the elevator on the outside of the building.

The storage area on the first floor is located in the former gallery area associated with A through $E$ cells. This area contains a toilet, change room, mechanical room, and space for storage. The storage area on the first floor is in an open area with arrays marked off or painted on the floor.

The storage area on the second floor is located in the former gallery area associated with A through $\mathrm{f}$ cells. The individual process cell sample galleries, which protrude into this area but are not part of the storage area, are sealed off. Storage on the second floor is in an open area, with arrays marked on the floor.

The storage area on the third floor is located in the former operating gallery area associated with cells A through $\mathrm{E}$.

Constant air monitoring of operating and storage areas on each of the 3 floors is provided by CAMs. The building HVAC system provides for contamination zone control in facility operating floor areas.

\section{B.3.4 T Plant}

The original buildings at T Plant were constructed in the mid-1940's to extract plutonium from production reactor fuel. The plant continued to perform this function until it was deactivated in 1956. Most of its original process equipment subsequently was removed. In 1957 T Plant was placed in service as a beta-gamma decontamination facility and as a support complex for experiments and other operations requiring containment or isolation. It currently functions primarily as a decontamination facility.

The T Plant Facility consists of two primary decontamination buildings: 221- $\mathrm{T}$ and 2706-T. Building 221-T was built during 1943 to 1944 . Building 221-T provides services in radioactive decontamination, maintenance and return-to-service, fuel storage (PWR Core II blanket fuel 
assemblies) and decommissioning of process equipment decontaminated with fission products and other highly contaminated pieces of equipment. The 2706-T Building was built during 1959 to 1960. Building 2706-T was constructed as a low-level radioactive decontamination facility and is used for waste verification and decontamination of railroad equipment, buses, trucks, automobiles, road-building equipment, and plant process equipment.

\section{B.4 Need for Upgrade}

This section is incomplete at this time. This section will be upgraded to provide a discussion of the extent to which the safety documentation does or does not meet the requirements of the Final Rules for each nuclear facility in the SWOC when this IP is upgraded to be the Rule Implementation plan.

\section{B.5 Applicability of Technical Standards}

This section is incomplete at this time. This section will be upgraded to identify the applicability of the DOE technical standards identified in section 3.1 of this plan for each SWOC nuclear facility when this IP is upgraded to be the Rule Implementation Plan.

\section{B.6 Basis for Interim Operations}

\section{B.6.1 Central Waste Complex}

The current SAFETY BASIS for the CWC is defined in WHC-SD-WM-SAR-049, "Central Waste Complex Final Safety Analysis Report - FSAD Upgrade." SWOC has completed the Interim Safety Basis (ISB) for the CWC (WHC-SD-WM-ISB-007, "Central Waste Complex Interim Safety Basis,") and has transmitted to DOE for approval (Hapke 1995).

\section{B.6.2 Burial Grounds}

The DOE approved safety basis for the Solid Waste Burial Grounds is established in the following collection of document:

- WHC-SD-WM-ISB-002, "Solid Waste Burial Grounds Interim Safety Basis,"

- WHC-SD-WM-SARR-028, "Solid Waste Burial Grounds Interim Safety Analysis," and

- WHC-SD-WM-TSR-001, "Solid Waste Burial Grounds Interim Operational Safety Requirements."

The DOE has determined that the collection of documents and the Safety Evaluation Report present an adequate and acceptable base for authorization of the analyzed operations at the facility (Wagoner 1995). 
WHC-SP-1164, Appendix B
Rev. 0

September 29, 1995

Page 5 of 5

\section{B.6.3 TRUSAF}

The current safety basis for TRUSAF is defined in the following documents:

- WHC-SD-WM-SAR-025; "Transuranic Waste Storage and Assay Facility Hazard Identification and Evaluation," and

- $\quad$ OSD-SW-153-00005, "Operating Specifications for TRUSAF."

The ISB for the facility has completed and is in WHC review. The interim safety basis for the facility until the SAR upgrade will be defined in WHC-SD-WM-ISB-004.

\section{B.6.4 T Plant}

The latest revision of the following documents define the current SAFETY BASIS documentation for T Plant:

- WHC-SD-CP-SAR-007, "T Plant Safety Analysis Report"

- $\quad$ OSD-D-187-00008, "Operating Specifications for the T Plant Facility"

The ISB for T Plant, WHC-SD-WM-ISB-006, "Interim Safety Basis for Solid Waste Facilities (T Plant)" has been completed and transmitted to DOE for review and approval.

\section{B.7 Plan and Schedule}

This section is incomplete at this time. This section will provide the plan and schedule to develop the upgraded safety analysis for each nonreactor nuclear facility in the SWOC when this plan is upgraded to be the Rule Implementation Plan. 
WHC-SP-1164

Appendix C

Approval Signature

reverent

L. W. Roberts, Facility Manager $\frac{9 / 2.265}{\text { Date }}$ 


\section{C.1 Mission}

The current mission of the 340 Waste Handling Facility is to support the laboratories located in the 300 Area operated by Pacifice Northwest Laboratory (PNL).

\section{C.2 Description of $\mathbf{3 4 0}$ Facility}

The 340 Facility serves as a radioactive/mixed liquid waste handling facility servicing Pacific Northwest Laboratories (PNL) located in the 300 Area. Waste is received at the facility from these laboratories via the Radioactive Liquid Waste System (RLWS), a series of underground pipelines. The facility accumulates, stores, and ships this waste via rail tank cars to the Double Shell Tanks (DSTs).

The facility also provides radioactive monitoring for nonhazardous, potentially radioactive, process sewer waste from the Retention Process Sewer (RPS). The facility maintains diverter stations in several 300 Area laboratories. These diverter stations monitor for radioactivity and if detected, divert waste to the Radioactive Liquid W.aste System (RLWS). If radioactivity is not detected, the waste is treated as industrially contaminated waste water and discharged accordingly.

\section{C.3 Need for Upgrade}

This section is incomplete at this time. This section will be upgraded to provide a discussion of the extent to which the safety documentation does or does not meet the requirements of the Final Rules when this IP is upgraded to be the Rule Implementation plan.

\section{C.4 Applicability of Technical Standards}

This section is incomplete at this time. This section will be upgraded to identify the applicability of the DOE technical standards identified in section 3.1 of this plan when this IP is upgraded to be the Rule Implementation Plan.

\section{C.5 Basis for Interim Operations}

The interim safety basis for the 340 Facility is established in WHC-SD-WM-ISB-003, "340 Waste Handling Facility Interim Safety Basis." The document has been reviewed and approved by the DOE (Teynor).

\section{C.6 Plan and Schedule for Upgraded SAR and TSRs}

This section is incomplete at this time. This section will provide the plan and schedule to develop the upgraded safety analysis when this plan is upgraded to be the Rule Implementation Plan. 

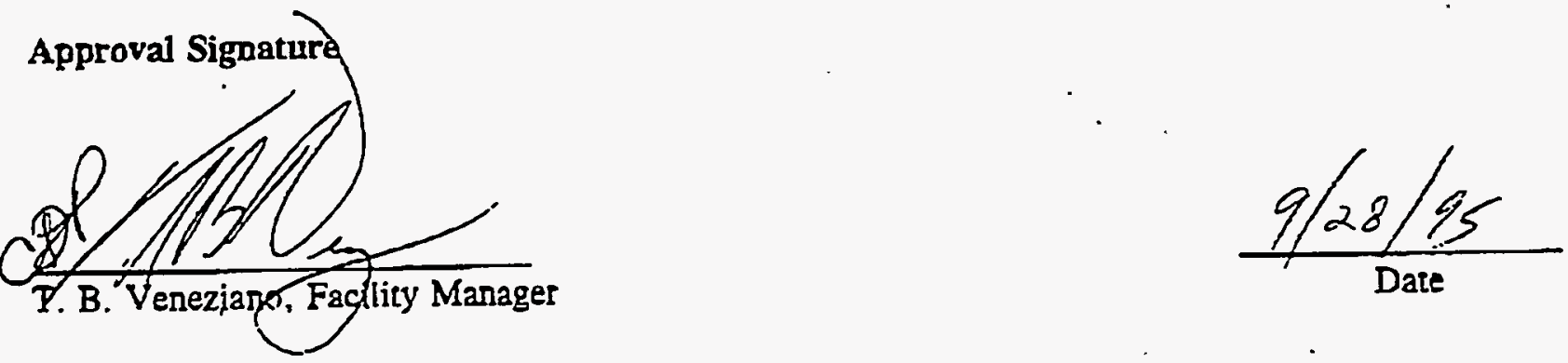


\section{D.1 Mission}

The $\mathrm{K}$ Basins mission is to provide safe, economic, environmentally sound management of the $\mathrm{K}$ Basins facility and the material stored in the $\mathrm{K}$ Basins.

\section{D.2 Description of $\mathbf{K}$ Basins Facility}

The 105KE and 105KW reactors, their irradiated fuel storage basins, and auxiliary facilities were built in the early 1950's and ceased operation in the early 1970's. All irradiated nuclear fuel from operation of the $105 \mathrm{KE}$ and $105 \mathrm{KW}$ reactors were removed from the basins at that time. The 105KE Irradiated Fuel Storage Basin was modified in 1974-1975 to store irradiated N Reactor fuel. In a similar manner the $105 \mathrm{KW}$ Irradiated Fuel Storage Basin was modified in 1980 to provide additional storage capacity for irradiate N Reactor fuel. Presently, approximately 2100 MTU of irradiated N Reactor fuel are stored in the two basins in about evenly divided quantities. A small quantity of irradiated Hanford single pass reactor fuel is also stored in each of the two basins.

The K Basins Facility includes the 105KE and 105KW Irradiated Fuel Storage Basins and certain 100-K Area auxiliary facilities required to support safe fuel storage in the basins. These auxiliary facilities include water pumping, treatment and discharge facilities, maintenance shops, electrical service facilities and office and laboratory space. The remaining presently unused 100-K Area facilities have been turned over to the Bechtel Hanford Company awaiting the eventual decontamination and decommissioning.

\section{D.3 Need for Upgrade}

This section is incomplete at this time. This section will be upgraded to provide a discussion of the extent to which the safety documentation does or does not meet the requirements of the Final Rules for $\mathrm{K}$ Basins when this IP is upgraded to be the Rule Implementation plan.

\section{D.4 Applicability of Technical Standards}

This section is incomplete at this time. This section will be upgraded to identify the applicability of the DOE technical standards identified in section 3.1 of this plan for K Basins when this IP is upgraded to be the Rule Implementation Plan.

\section{D.5 Basis for Interim Operations}

The present safety basis documents provide adequate controls to safely operate the $\mathrm{K}$ Basins and supporting facilities. The SAR analyzes a variety of fuel storage, handling and shipping accidents. Required controls are applied via the OSR's and lower tier documents to maintain operations within the safety authorization.

The Operations Safety Requirements document (WHC-SD-WM-OSR-006) and the Safety Analysis Report document (WHC-SD-WM-SAR-062) do not meet current DOE requirements for format and content. In addition, there are entries in both documents that are no longer consistent with the present configuration of the facilities that are in need of updating. 
The following documents define the SAFETY BASIS for the K Basins facility.

- WHC-SD-WM-SAR-062, "Safety Analysis Irradiatẹ N Reactor Fuel,"

- WHC-SD-WM-OSR-006, "Operations Safety Requirements - $100 \mathrm{KE}$ and $100 \mathrm{KW}$ Fuel Storage Basins," and

- WHC-SD-SNF-HC-001, "K Basins Fuel Encapsulation and Storage Hazard Categorization."

The K Basins facility has completed their Interim Safety Basis documentation. These documents have been transmitted to DOE for review and approval (Reference 1). Reference 2 indicated RL was not prepared to approve the submitted updated SAR and IOSRs as the authorization basis for the $\mathrm{K}$ Basins until:

1. the annual update SAR and IOSRs were updated to reflect the installed seismic isolation barriers, and

2. the radiological and non-radiological accident consequence calculations were performed using the near river bank as the site boundary, or provide adequate justification for the selected on-site and off-site locations.

In Reference 3, $\mathrm{K}$ Basins committed to submit the annual update SAR analysis, along with the changes to account for the seismic isolation barrier installation for the 1995 annual SAR update. The radiological accident consequences had already been performed for the near river bank in the safety analysis document, WHC-SD-SNF-RA-001 which was referenced in the reference 1 SAR. Reference 3 also provide the justification for not changing the current authorized site boundary as being outside WHC authority and requiring direction from DOE. The annual update SAR (References 4 and 5 ) is currently undergoing $R L$ review and $\mathrm{K}$ Basin response to comments. Approval of the annual update SAR is currently scheduled by RI for the end of October 1995. The IOSRs will then be updated based on the approved annual update SAR and submitted for RL review and approval.

Concurrent with this updating activity several old operational safety requirements are being individually submitted for deletion or change as supported by the updated accident analyses in support of more efficient and cost effective operation.

\section{D.6 Plan and Schedule for Upgraded SAR and TSRs}

After RL approval of the 1995 annual update of the SAR as the Interim Safety Basis, K Basins intends to request a waiver to DOE Order 5480.23 SAR upgrade based on the limited remaining life of the facility, limited hazard and no active engineered safety structures, systems or components.

This section is incomplete at this time. This section will provide the plan and schedule to develop the upgraded safety analysis as appropriate for the $\mathrm{K}$ Basin facility when this plan is upgraded to be the Rule Implementation Plan. 


\section{D.7. References}

1. Truax, J. E. to J. L. Daily, "Transmittal of WHC-SD-SNF-ISB-001, Revision 0, 'K Basins Interim Safety Basis,' WHC-SD-SNF-SAR-001, Revision 0, 'K Basins Safety Analysis Report,' and WHC-SD-SNF-TSR-001, Revision 0, 'KE and KW Fuel Storage Basins Interim Operational Safety Requirements' for Approval," Letter, November 29, 1994.

2. Sellers, R. L. to President, WHC, "Review of Safety Basis for K Basins," Letter, April 19, 1995.

3. Veneziano, T. B. to E. D. Sellers, "K Basins Safety Analysis Report," Letter, June 13, 1995.

4. Veneziano, T. B. to E. D. Sellers, "K Basins Safety Analysis Report 1995 Annual Update," Letter, June 29, 1995.

5. Veneziano, T. B. to E. D. Sellers, "Revision to Chapter 10 and 11 of WHC-SD-WM-SAR-062 Approval Submittal," Letter, August 23, 1995. 


\section{Approval Signature}

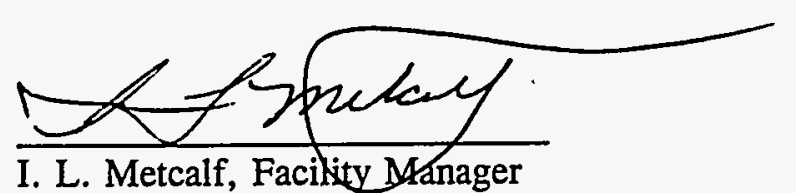

I. L. Metcalf, Facility Manager

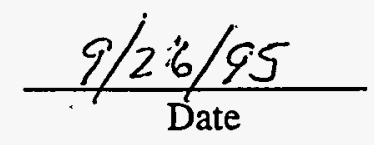




\section{E.1 Mission}

The Fuel Supply Shutdown Facility (FSSF) is used primarily for storage of unirradiated fuel that was manufactured for use in the plutonium production reactors. Individual facilities within this grouping will be turned over for decontamination and decommissioning activities once their usage is terminated, RCRA TSD closure actions completed, deactivation completed, and transfer of ownership negotiated.

\section{E.2 Description of Fuel Supply Shutdown Facility}

The FSSF is comprised of a variety of buildings, including two major structures, the 313 and 333 Buildings. The primary fuel fabrication operations were conducted in 333 . The remaining structures were used as support buildings to the fabrication operations.

The FSSF has ceased operations and are in transition to shutdown for turnover for decommissioning. Fissionable material movements have stopped except for waste packaging and no significant movement is planned until ultimate disposal is approved. Sale of the uranium fuel to private and governmental activities is being aggressively pursued.

The history of the FSSF Facility began in 1943 when the 313 Building was constructed to house manufacturing equipment for the Hanford single pass reactors fuel. Fuel production began in mid 1944, and continued through the early 1950's. The facility was then expanded to allow for increased fuel production. In the late 1960 's, a process, which included nickel plating of the bare uranium cores prior to cladding, was developed and installed. This process continued until 1971, when the production line was shut down along with the single pass reactors. Other programs conducted at the 313 Building include support of a tritium production program from 1948 to 1952 and a thorium program in the late 1960's. For N Reactor Fuel Fabrication, the $76,199 \mathrm{ft}^{2} 313$ Building provided waste treatment system, administrative offices, training, and warehouse space. This building also houses a complete $\mathbf{N}$ Reactor pressure tube fabrication facility consisting of a 4000 Ton Sutton extrusion press, draw bench, grinders, autoclaves, inspection, equipment and chemical cleaning equipment. This Hanford Metal Working Facility has been privatized. The equipment has been sold to a division of Kaiser Aluminum and Chemical Company who is leasing the facility until permanent facilittes are constructed.

The 333. Building, constructed in 1958, houses the primary fabrication equipment for manufacturing $\mathrm{N}$ Reactor fuel. Fuel fabrication operations began in 1962. From 1965 to 1967 , the facility was also used to construct lithium aluminate targets for demonstration of co-production in the $\mathrm{N}$ Reactor. The 46,633 $\mathrm{ft}^{2}$ building contained equipment for all operations from initial component cleaning to finished fuel assembly, inspection, and packaging for shipment. Fabrication activities continued until $\mathrm{N}$ Reactor entered the standby phase in 1987.

\section{E.3 Need for Upgrade}

This section is incomplete at this time. This section will be upgraded to provide a discussion of the extent to which the safety documentation does or does not meet the requirements of the Final Rules for each nuclear facility when this IP is upgraded to be the Rule Implementation plan.

The FSSF is in the final life cycle stage prior to D\&D. It is anticipated that the facility will not upgrade the ISB to meet the requirements of the Rule. 


\section{E.4 Applicability of Technical Standards}

This section is incomplete at this time. This section will be upgraded to identify the applicability of the DOE technical standards identified in section 3.1 of this plan when this IP is upgraded to be the Rule Implementation Plan.

\section{E.5 Basis for Interim Operations}

The interim safety basis for FSSF is documented in WHC-SD-NR-ISB-001, "Interim Safety. Basis for 300 Area N Reactor Fuel Fabrication and Storage Facility," and WHC-SD-NR-TSR-001, "300 Area N Reactor Fuel Fabrication and Storage Facility Technical Safety Requirements." DOE has approved the ISB for FSSF.

\section{E.6 Plan and Schedule for Upgraded SAR and TSRs}

This section is incomplete at this time. This section will provide the plan and schedule to develop the upgraded safety analysis when this plan is upgraded to be the Rule Implementation Plan. The FSSF is in the final life cycle stage prior to D\&D. It is anticipated that the facility will not upgrade the ISB to meet the requirements of the Rule. 
Approval Signature
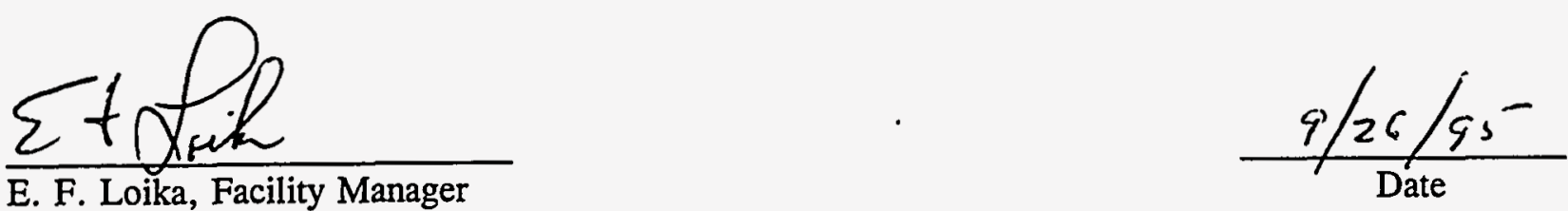


\section{F.1 Mission}

The Fast Flux Test Facility (FFTF) is currently in the Transition Phase of the decommissioning process.

\section{F.2 Description of Fast Flux Test Facility}

The FFTF is located on the U.S. Department of Energy Hanford Site near Richland, Washington, and is operated by the Westinghouse Hanford Company. This facility was designed specifically for irradiation testing of nuclear reactor fuels and materials for liquid-metal-fast-breeder reactors. The term Fast Flux Test Facility includes the reactor as well as the equipment and structures for heat removal, containment, core component handling and examination, instrumentation and control, and for supplying utilities and services such as emergency power generation and irradiated fuel storage. The reactor vessel has been defueled.

The FFTF Plant, both the FFTF reactor plant and the Fuel Storage Facility (FSF) are in the "Transition phase." The Reactor and several FFTF support systems have been shutdown as have several FSF support systems. Most FFTF systems presently operating are scheduled for shutdown in 1997, commensurate with primary sodium drain. The following items, when taken in the aggregate, dramatically decrease the actual hazards associated with FFTF:

- $\quad$ All fuel has been removed from the FFTF reactor and placed in one of two sodium filled storage vessels. Reactor operation is no longer possible.

- Decay heat of the fuel has decreased to very low values and no active cooling is required.

- Fuel pin fission gas inventory has decreased to a relatively low level.

- The radioactivity level of the sodium has significantly decreased thus minimizing the consequence of a sodium leak and fire.

- Nominal sodium temperatures have been reduced to $400{ }^{\circ} \mathrm{F}$.

- The operational complexity of FFTF has markedly decreased due to the defueled reactor and system/component shutdown.

\section{F.3 Need for Upgrade}

This section is incomplete at this time. This section will be upgraded to provide a discussion of the extent to which the safety documentation does or does not meet the requirements of the Final -Rules when this IP is upgraded to be the Rule Implementation plan.

FFTF is in its final life cycle stage and is not anticipated to upgrade the existing authorization basis to meet the requirements of the final Rules. 


\section{F.4 Applicability of Technical Standards}

This section is incomplete at this time. This section will be upgraded as appropriate to identify the applicability of the DOE technical standards identified in section 3.1 of this plan when this IP - is upgraded to be the Rule Implementation Plan.

\section{F.5 Basis for-Interim Operations}

The following documents define the SAFETY BASIS for FFTF:

- TI-75002, "Final Safety Analysis Report for the Fast Flux Test Facility, Volumes 1 - 10"

- WHC-EP-0132, "Fuel Storage Facility Final Safety Analysis Report, Amendment 4"

\section{F.6 Plan and Schedule for Upgraded SAR and TSRs}

This section is incomplete at this time. This section will provide the plan and schedule to develop the upgraded safety analysis if needed when this plan is upgraded to be the Rule Implementation Plan. FFTF is in its final life cycle stage and is not anticipated to upgrade the existing authorization basis to meet the requirements of the final Rules. 
Approval Signature
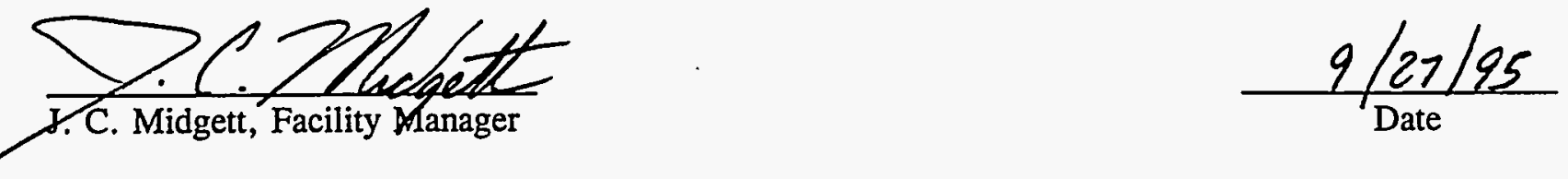


\section{G.1 Mission}

DOE eliminated B Plant from any future processing missions due to the difficulties of bringing a 46 year old plant up to current environmental standards. Since that time B Plant has continued to operate, ensuring safe storage and management of approximately 75 megacuries of cesium and strontium capsules in Waste Encapsulation Storage Facility (WESF) as well as substantial radioactive contamination and residual inventory from past operations.

The current mission is to place B Plant into a safe, cost-effective configuration, allowing for longterm surveillance until final decontamination and decommissioning and to ensure safe storage of the cesium and strontium capsules at WESF.

\section{G.2 Description of B-Plant/WESF}

The B Plant facility at the Department of Energy's (DOE) Hanford Site is located in the south central region of Washington State. The plant was constructed between 1943-45 and was originally designed to process spent nuclear fuels in support of the Manhattan Project. After its original mission was completed, the plant was modified from 1961-1967 for the separation of strontium and cesium from the fissile product waste stream from the Plutonium-Uranium Extraction Plant (PUREX). The recovered, purified, and concentrated strontium and cesium solutions were then transferred to the Waste Encapsulation and Storage Facility (WESF) for conversion to solid compounds, encapsulation, and interim storage. These $\mathrm{Cs} / \mathrm{Sr}$ separation campaigns were conducted at B Plant from 1974 to 1985.

There is a substantial quantity of radioactive inventory remaining in B Plant in the form of stored liquid organics (leftover from previous NCAW pilot run), kilocurie quantities of solid particulate strontium and cesium contained in underground high efficiency particulate air (HEPA) filters, and a highly contaminated facility structure.

\section{G.3 - Need for Upgrade}

This section is incomplete at this time. This section will be upgraded to provide a discussion of the extent to which the safety documentation does or does not meet the requirements of the Final Rules when this IP is upgraded to be the Rule Implementation plan.

The need for an upgrade will be addressed separately for each facility.

\section{G.4 Applicability of Technical Standards}

This section is incomplete at this time. This section will be upgraded to identify the applicability of the DOE technical standards identified in section 3.1 of this plan when this IP is upgraded to be the Rule Implementation Plan. 
WHC-SP-1164,

Appendix G
WHC Safety Analysis Report and Technical Safety

Requirements Upgrade Program
Rev. 0

September 29, 1995

Page 2 of 2

\section{G.5 Basis for Interim Operations}

The following documents define the SAFETY BASIS for B-Plant/WESF:

- WHC-SD-WM-SAR-005, "Waste Encapsulation and Storage Facility Safety Analysis Report"

- WHC-SD-WM-SAR-008, "212-B Cask Station Facility Hazards Identification and Evaluation"

- WHC-SD-WM-SAR-013, "B Plant Safety Analysis Report"

B Plant has defined their interim credible accidents, restrictions, and operating controls and transmitted to DOE for review and approval in the following documents:

- WHC-SD-WM-ISB-008, "B Plant Interim Safety Basis,"

- WHC-SD-WM-SARR-030, "B Plant Interim Safety Basis Accident Analysis,"

- WHC-SD-WM-TM-004, "B Plant Facility Description."

The collection of documents above will be the authorization basis for B Plant when DOE approves the documents.

WESF is currently developing the interim safety basis for the facility. The document is scheduled to be submitted to DOE in September 1996.

\section{G.6 Plan and Schedule for Upgraded SAR and TSRs}

This section is incomplete at this time. This section will provide the plan and schedule to develop the upgraded safety analysis when this plan is upgraded to be the Rule Implementation Plan.

Separate facility-specific plans will be submitted in the Rule IP. 


\section{Approval Signature}

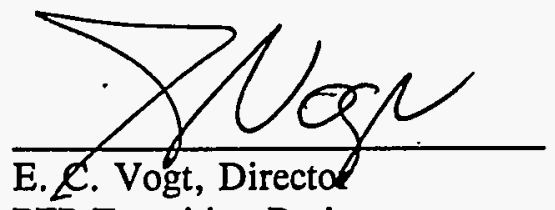

PFP Transition Project

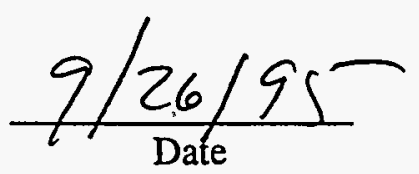




\section{H.1 Mission}

No long-term production mission is currently planned for the PFP. The near-term operational objective of the PFP Transition Project is to process the plutonium nitrate solutions and solid process residues currently in storage to a stable form for interim and long term storage at the facility and to clean out the facility (equipment, glovebox, and canyon floor) so that it can be placed in safe standby status.

The PFP went into an outage in December 1989, for routine maintenance following completion of a plutonium conversion campaign. The maintenance outage was subsequently extended to incorporate a general review and enhancement of safety systems and practices. At the time of the outage, the mission of the facility was to receive the plutonium nitrate product solution from the PUREX Plant and convert the plutonium to metal buttons. The DOE directed that PUREX and Plutonium Finishing Plants be placed in standby mode until an appropriate evaluation could be completed to document the acceptability of the future mission for the facility.

At the time of the outage, most of the feed and storage tanks in the PRF were full of plutonium solution of various concentrations and purity. These solutions have been downloaded into storage containers. It is essential that the plutonium in these solutions be converted to a stable form, that the facility equipment, gloveboxes, and canyon floor be flushed, and the plutonium in the flush solutions be processed to a stable form in order to ensure a safe standby status for the facility.

The Plutonium Finishing Plant Transition Project mission is to prepare and implement the Record of Decision (ROD) resulting from the PFP Stabilization Environmental Impact Statement (EIS). The activities evaluated by this EIS to be implemented at PFP include:

- Stabilizing reactive residual plutonium-bearing materials at PFP to a form suitable for longterm storage

- Removing readily retrievable plutonium-bearing materials left behind in process equipment, process areas, and air quality and liquid waste management systems as a result of historic use

- Storing stabilized fissile material in existing vaults at the PFP pending a DOE decision on ultimate. storage or disposition of the materials.

Interim actions to resolve immediate safety concerns are currently being taken. This includes stabilizing reactive scrap, removing ventilation duct work, and clean up of radioactive surface contamination as well as routine operations and maintenance.

\section{H.2 Description of the Plutonium Finishing Plant}

The PFP complex is comprised of a large number of buildings, many of which are relatively small structures and do not fit the definition of a nonreactor nuclear facility. The majority of the operations and activities, however, are conducted in a few "major" buildings, as described in the following paragraphs. 


\section{Building 234-5-Z}

The 234-5-Z building is of steel frame construction, approximately $500 \mathrm{ft}$ long by $180 \mathrm{ft}$ wide, with four floor levels. Internal features include reinforced concrete walls surrounding the processing area, several vault-type rooms with thick, reinforced concrete walls and ceilings, and two reinforced concrete stairwells.

The 234-5-Z building was originally constructed to house plutonium reduction operations, plutonium machining operations, and analytical laboratory services. Current building activities include: process support work in the Analytical Laboratory and the Plutonium Process Support Laboratory; plutonium product, solution, scrap and solid waste handling operations; stabilizing reactive scrap; removing ventilation duct work; clean up of radioactive surface contamination; and routine operations and maintenance. The $232-\mathrm{Z}$ incinerator building contents and support equipment are being removed in preparation for Decontamination and Decommissioning (D\&D) of the building.

\section{Building 236-Z}

The 236- $\mathrm{Z}$ building is a reinforced concrete, above ground, canyon-type structure, $79 \mathrm{ft}$ by $71 \mathrm{ft}$ by $47.5 \mathrm{ft}$ high and surmounted by a 22.5 -ft-high penthouse on the southwest corner. The building is adjacent to the southeast corner of Building 234-5-Z.

Building 236-Z houses the Plutonium Reclamation Facility (PRF) process equipment and services for Miscellaneous Treatment (MT) (scrap dissolution), Slag \& Crucible dissolution, filtrate concentration, feed preparation, plutonium solvent extraction, product concentration, and Waste Tank processes. The PRF is capable of producing a high purity plutonium nitrate solution from a variety of feed sources by means of continuous countercurrent solvent extraction process equipment located in the canyon cell.

\section{Building $241-\mathrm{Z}$}

Building 241-Z covers a below-grade liquid waste collection system containing five tanks in five separate covered cells. This Radioactive Liquid Waste Facility is used for intermediate storage and neutralization of PFP aqueous wastes and is in an active status. After neutralization, the wastes are pumped to the 244-TX Tank Farm facility. A steam jet is also provided for transfer of the pump heel. Ventilation is provided for the cells and the tanks; the building is ventilated through the cells.

\section{Building 291-Z and 291-Z-1 Stack}

Building 291-Z houses seven electric motor-driven fans that provide ventilation exhaust for Buildings $234-5-Z, 242-Z$, and $236-Z$. The exhaust air is discharged to the atmosphere through the 200-ft-tall 291-Z-1 exhaust stack. These fans plus two steam-driven exhaust turbines (for backup capability) and the inlet and exhaust plenums are the primary features of Building 291-Z. The 291-Z Building ventilation supply and exhaust system is used only to remove the heat generated by the motors and other $291-Z$ equipment. Evaporative coolers provide supply air cooling in summer; exhaust is provided by gravity damper exhaust outlets. 


\section{Building 2736-Z Complex}

The 2736-Z Support Storage Complex consists of Buildings 2736-Z, 2736-ZA, 2736-ZB, and 2721-Z.

Building 2736-Z is designated the primary Plutonium Storage Facility (PSF). Building 2736-ZA provides exhaust ventilation for 2736-Z; Building 2736-ZB is utilized for shipping, receiving, repackaging, and Non-destructive Assay of Special Nuclear Materials; and Building 2721-Z provides backup electrical power.

These four buildings house all functional operations, other than analytical laboratory services, required to make the $2736-Z$ Support Complex self-sufficient. All four buildings have been designed or modified to meet current seismic and extreme wind resistance design criteria.

\section{H.3 Need for Upgrade}

This section is incomplete at this time. This section will be upgraded to provide a discussion of the extent to which the safety documentation does or does not meet the requirements of the Final Rules when this IP is upgraded to be the Rule Implementation plan.

\section{H.4 Applicability of Technical Standards}

This section is incomplete at this time. This section will be upgraded to identify the applicability of the DOE technical standards identified in section 3.1 of.this plan when this IP is upgraded to be the Rule Implementation Plan.

\section{H.5 Basis for Interim Operations}

The PFP does not have a Basis for Interim Operations. It has an approved Authorization Basis. The Authorization Basis or Safety Basis for the Plutonium Finishing Plant facility is contained in WHC-SD-CP-SAR-021, Rev 0, "Plutonium Finishing Plant Safety Analysis Report" and WHCSD-CP-OSR-010, "Plutonium Finishing Plant Operational Safety Requirements, " which have been approved by DOE. These documents combine and upgrade the information, analyses, requirements, and controls that were previously contained in 14 older safety documents. Other information related to the safety basis is contained in the WHC manuals addressing institutional topics such as Radiation Protection, Chemical Safety, Industrial Safety, Industrial Hygiene, Fire Protection, etc.

The SAR incorporates new structural/seismic analyses, as well as more comprehensive accident analyses, a new design basis accident appropriate to the plants mission, and mitigating responses, and abnormal operations analyses. WHC has performed an evaluation of the new SAR in relation to the more explicit requirements of DOE Order 5480.23. Implementation of the Operational Safety Requirements (OSR) contained in WHC-SD-CP-OSR-010, combined with well-established institutional programs for Radiation Protection, Industrial Safety, Chemical Safety, Industrial Hygiene, Fire Protection, etc. at the PFP meets the content requirements of DOE Orders 5480.21, 5480.22 , and 5480.23 , although format requirements are not fully met. An extensive review of the configuration of the PFP facility and operations (structures, systems, and components, as well as operating and institutional control documents) was conducted to ensure complete implementation 
of the safety related requirements and conditions of the new SAR, as well as the intent of the new Order. Technical criteria were prepared to provide guidance and assure a consistent and comprehensive approach in the development of a safety/authorization basis document. The criteria address the identification of safety related equipment/systems, operating control documents, and essential facility drawings, and the development of surveillance requirements. Specific guidance is provided regarding identification of equipment and systems that define the safety envelope and identification of "critical" procedures. Surveillance requirements implied by and developed in response to the assumptions of the accident analyses, as well as those required in the OSRs are in place. Finally, the criteria identified actions for achieving compliance with the new OSRs and implementation of the new SAR/OSRs into the facility operating instructions, controls, and practices. This work is complete, negating the need for a separate Interim Safety Basis (ISB) document and administrative controls.

Because of the absence of a long-term operating mission and the adequacy of the SAR, there are no plans to revise the new SAR to bring it into full format compliance with DOE Order 5480.23. Yearly updates to address current mission requirements will continue to be prepared. The safety/authorization basis will remain valid until a new SAR addressing facility standby and D\&D is prepared and approved.

\section{H.6 Plan and Schedule for Upgraded SAR and TSRs}

There is no plan for upgraded TSRs (OSRs), nor is a plan necessary. The PFP OSRs in WHC-SD-CP-OSR-010 meet the requirements of DOE Order 5480.22 in both content and format. 


\section{Approval Signature}
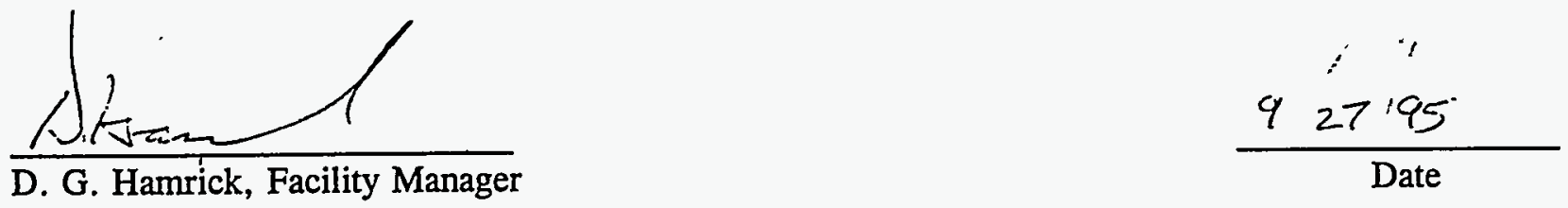


\section{I.1 Mission}

PUREX facility was placed in a maintenance outage during the third quarter of 1990 . During the fourth quarter of 1990 , DOE directed that the facility transition to a standby mode pending the outcome of an Environmental Impact Statement (EIS) on the alternatives for disposition of the Hanford irradiated fuel. Processing of the irradiated fuels at the PUREX facility was one of the alternatives under review. Before the facility was directed to maintain a standby mode, its mission was to reprocess irradiated fuels for the recovery of uranium and plutonium. The final EIS and Record of Decision (ROD) was not expected for approximately three to five years.

The standby condition was achieved in September 1992. However, in December 1992, the DOE Assistant Secretary for Environmental Restoration and Waste Management authorized the termination of PUREX and $\mathrm{UO}_{3}$ Plants and directed $\mathrm{RL}$ to proceed with shutdown planning and terminal cleanout activities. Presently, deactivation activities at the PUREX facility are well underway.

The objective of the PUREX/UO ${ }_{3}$ Deactivation Project is to establish a passively safe and environmentally secure facility configuration to be maintained for up to ten years or greater. The ten year period represents the typical time duration expended to define, authorize, and initiate the follow-on decontamination and decommissioning (D\&D) activities. The PUREX/UO3 Deactivation Project Management Plan contains overall direction for transitioning the facilities to a fully deactivated end state. The Project combines the existing standby activities (which will be gradually phased out) with newly defined deactivation activities.

\section{I.2 Description of PUREX}

The 202-A building, consists of three main structural components: (1) a thick-walled, heavily shielded concrete portion called the canyon which contains remote process cells and equipment; (2) a section comprised of three gallery levels parallel to and isolated from the canyon; and, (3) a steel transite annex to the north of the gallery section which houses offices. In addition to these structures, the laboratory, and a number of building service areas are encompassed in the PUREX facility.

The structures in the 202-A building are built to safely handle materials of varying degrees of radioactivity. The canyon structure with below-grade, isolated chemical processing cells was selected as being most appropriate for a bulk radiochemical separations operation. Structures built prior to 1968, which include the 202-A canyon and most of the other structures handling highly radioactive materials, were designed for typical static vertical live and dead loads in accordance with uniform building codes, Hanford Facility Standards, and other applicable design documents in effect at the time of construction. Structures built after 1968, with the exception of the third PUREX filter, were designed for the most severe possible combination of dead, live, and operating loads appropriate for the given criteria. Seismic provision is made in the load calculations for a maximum credible earthquake producing a $0.25 \mathrm{~g}$ horizontal ground acceleration and a $0.17 \mathrm{~g}$ vertical acceleration.

The PUREX facility is comprised of several regulated areas. Regulated areas are those areas which are involved in the treatment, storage, and accumulation of radioactive regulated wastes. 
Regulated wastes are those wastes defined by state and federal regulations and include both radioactive and non-radioactive chemical wastes (including lead and silver).

Before the PUREX facility was placed in a standby condition, its mission was to reprocess irradiated fuels for the recovery of uranium and plutonium. The program to design and construct the PUREX Plant (202-A building) and the associated support facilities was initiated in 1952 by the U.S. Atomic Energy Commission (now DOE). The PUREX Plant was one of the mainstays in the United States' nuclear fuel separations program, processing irradiated production reactor fuels for the recovery of uranium and weapons- or fuels-grade plutonium. From the first operation in 1956 to shutdown in September 1972 and from its restart in 1983 to being standby in 1990, refinements were made in the Plant to upgrade Safety and Process equipment, achieve process versatility, and adapt to changing feed material.

Hanford's PUREX Facility was designed and constructed to provide supplemental fuel reprocessing capability to separate plutonium and uranium products from irradiated fuel. The facility is operated by Westinghouse Hanford Company (WHC) under the direction of the U. S. Department of Energy (DOE). The PUREX process, developed at Oak Ridge National Laboratory (ORNL), Oak Ridge, Tennessee, was used as an improvement over the REDOX process.

The PUREX facility and process was originally designed to reprocess aluminum-clad uranium metal fuel to recover weapons-grade plutonium and natural enriched uranium, but later modified to reprocess zirconium alloy (Zircaloy) clad fuel from $\mathrm{N}$-Reactor to recover plutonium and uranium. This process assisted programs, such as research, reactor development, safety, and the United States defense; plus, provide uranium for fuel in reactors generating electricity and plutonium.

Since its first process using spent fuel in 1956, a variety of fuels have been reprocessed. The fuel enrichments have varied from $0.72 \%$ to $2: 1 \%{ }^{235} \mathrm{U}$; fuel exposures have varied from 300 to 3,000 $\mathrm{MWd} / \mathrm{t} \mathrm{U}$; and cooling times have varied from 120 days to 7 years. Aluminum-clad and zirconium-clad fuels have been processed at the PUREX facility. Types of fuels processed include uranium metal, uranium and plutonium oxides ( $\mathrm{Pu}$ and $\mathrm{Al}$ alloys), and thoria targets. During operations, improvements were made to increase production rates, provide diverse capability to handle various fuels, provide higher quality products, decrease environmental releases, and improve the safety of the operation. Additional changes were made while the plant was in standby between September 1972 and November 1983.

\section{I.3 Need for Upgrade}

This section is incomplete at this time. This section will be upgraded to provide a discussion of the extent to which the safety documentation does or does not meet the requirements of the Final Rules when this IP is upgraded to be the Rule Implementation plan. The PUREX facility is in its final life cycle stage and is not anticipated to upgrade the existing authorization basis to meet the requirements of the final Rules. 
WHC-SP-1164,

Appendix I
WHC Safety Analysis Report and Technical Safety

Requirements Upgrade Program
Rev. 0

September 29, 1995

Page 3 of 3

\subsection{Applicability of Technical Standards}

This section is incomplete at this time. This section will be upgraded to identify the applicability of the DOE technical standards identified in section 3.1 of this plan when this IP is upgraded to be the Rule Implementation Plan.

\section{I.5 Basis for Interim Operations}

The following documents define the current AUTHORIZATION BASIS/SAFETY BASIS documentation for the PUREX facility (Wagoner 1994a and Wagoner 1994b):

- WHC-SD-HS-SAR-001, "PUREX Plant Final Safety Analysis Report"

- WHC-CM-4-46, Nonreactor Facility Safety Analysis Manual, Section 7.3.2, and 7.4.2 associated with nonradiological risk, or current versions and the M\&O Toxic Chemical Hazard Classification and Risk Acceptance Guidelines for Use in DOE Facilities, WSRCMS-92-206, Revision 1, April 1993. 4

- Hazard Identification and Evaluation (HI\&E) reports prepared as addendums to the FSAR to reflect project upgrades

Based on the implementation of the referenced letter and time schedule for completion of the PUREX deactivation project, no formal ISB or Basis for Interim Operation (BIO) document will be prepared for PUREX Deactivation. Considering the time and budget constraints as well as continuing modifications to the facility conditions and reduction of inventories, there is no identified value added in the development of additional safety basis documents for this project. The use of the USQ process based on the authorization basis as identified above, combined with a hazards assessment process will provide the necessary identification and control of issues important to the safe deactivation of the PUREX facility in a timely and cost effective manner.

An Operating Specification Document (OSD) for the deactivation mode was developed to ensure the adequate implementation of controls as identified in the PUREX FSAR chapter 11 OSRs. The OSD replaced the Process Control Manual Addendum I (WHC-CM-5-24, Add I) and implemented the OSRs contained in Chapter 11 of the FSAR. The OSD was written in the standard format per procedure 2.32 of WHC-CM-5-9, "PUREX/UO ${ }_{3}$ Plant Administration Manual." The OSD has been issued and will be maintained under WHC control. This change reflects the reduced potential (chemicals, SNM. etc.) for events causing unacceptable consequences during Deactivation.

\section{I.6 Plan and Schedule for Upgraded SAR and TSRs}

This section is incomplete at this time. This section will provide the plan and schedule to develop the upgraded safety analysis when this plan is upgraded to be the Rule Implementation Plan. The PUREX facility is in its final life cycle stage and is not anticipated to upgrade the existing authorization basis to meet the requirements of the final Rules. 


\section{Approval Signature}

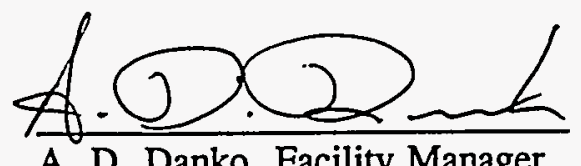

A. D. Danko, Facility Manager

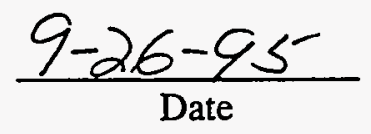




\section{J.1 Mission}

The 308 Building and Fuel Storage Annex (formerly NRF TRIGA Reactor) were operated to provide laboratories and fuel fabrication facilities for the development of reactor fuels containing plutonium.

The main 308 Building has been placed in lay up condition with the major support systems shut down including the gloveboxes and ventilation systems. There is minimal residual fissionable material inventory contained within gloveboxes and ventilation systems. No operations are planned except for minimal maintenance and surveillance activities.

The Fuel Storage Annex (FSA) has-a TRIGA reactor fuel inventory of almost 4 kilograms Uranium 235 located in fuel storage racks outside the core reflector and suspended in the tank periphery. The reactor fuel is water shielded. The current mission of the FSA is to maintain a shutdown condition with minimal surveillances to verify integrity of radioactive components and radiation boundaries is maintained. Preparation to remove the irradiated TRIGA fuel from the FSA (including approved NEPA documentation) are complete. Fuel removal and final deactivation tasks will be completed in fiscal year 1996 and turnover to D\&D contractor will be pursued by year end.

\section{J.2 Description of the 308 Building}

The 308 Building is a two story structure constructed of reinforced concrete, concrete block, and steel siding. It was designed as a multipurpose nuclear facility for the development and fabrication of nuclear reactor fuel. The building, erected in 1960, has undergone several additions since the original construction to reach the current 71,000 square feet.

The facility will no longer be used for nuclear fuel development or fabrication and is currently in transition to shutdown for turnover, remedial action and/or decommissioning. All nuclear materials used in the fuel fabrication process have been removed from the building with the exception of relatively small amounts of plutonium oxide powder held up in the gloveboxes and associated exhaust ducting. Decontamination has reduced the material retained in gloveboxes and enclosures to a total of less than 400 grams of plutonium (WHC 1992b). Approximately 20 grams of material also remain in the ventilation exhaust ducting.

The facility also contains a neutron radiography facility TRIGA Reactor located in an annex of the Building. This $250 \mathrm{KW}$ reactor was used to prepare neutron radiographs of FFTF Reactor fuel pins fabricated by offsite vendors and in the 308 building.

The reactor is currently shutdown and fuel has been placed within storage racks in the reactor water pool in preparation for eventual fuel removal.. The downloaded TRIGA reactor has been designated as a fuel storage basin, and is being monitored under the RL approved shutdown plan and Interim Safety Basis document. The ultimate disposition of the fuel is uncertain, but interim storage of the fuel at the 400 Area Interim Storage Area along with the FFTF fuel will be initiated in fiscal year 1996. 


\section{J.3 Need for Upgrade}

This section is incomplete at this time. The 308 Building is in it's final life cycle stage and is not anticipated to upgrade the existing authorization basis to meet the requirements of the final Rules. This section will be upgraded, if needed, to provide a discussion of the extent to which the safety documentation does or does not meet the requirements of the Final Rules when IP is upgraded to be the Rule Implementation plan.

\section{J.4 Applicability of Technical Standards}

This section is incomplete at this time. This section will be upgraded as appropriate to identify the applicability of the DOE technical standards identified in section 3.1 of this plan when this IP is upgraded to be the Rule Implementation Plan.

\section{J.5 Basis for Interim Operations}

The DOE approved Interim Safety Basis, WHC-SD-FL-ISB-001, "Interim Safety Basis for the 308 Building," defines the authorization basis for the 308 Building.

\section{J.6 Plan and Schedule for Upgraded SAR and TSRs}

This section is incomplete at this time. This section will provide the plan and schedule to develop the upgraded safety analysis when this plan is upgraded to be the Rule Implementation Plan.

The 308 Building is in it's final life cycle stage and is not anticipated to upgrade the existing authorization basis to meet the requirements of the final Rules. 
Approval Signature
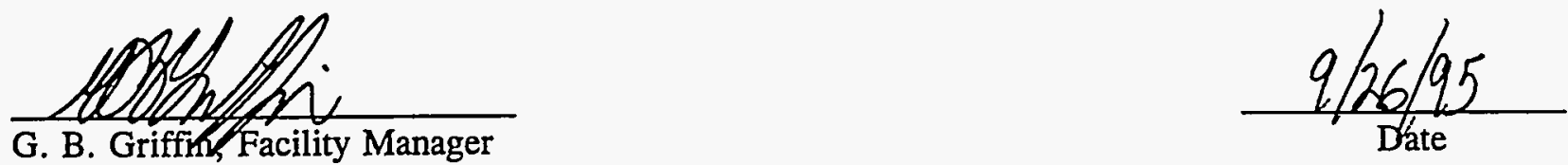


\section{K.1 Mission}

The current mission of the 222-S Laboratory Complex is as follows: Activities at the 222-S Laboratory will continue to expand as the result of relatively new programs arising from hazardous waste activities. New efforts are expected to include sample analyses as defined in the Environmental Protection Agency (EPA) SW-846 Manual and/or in the EPA Comprehensive Environmental Response Compensation and Liability Act (CERCLA) Contract Laboratory Program. The 222-S Laboratory is also likely to support development of procedures for the Hanford Waste Vitrification Plant and continue to increase its environmental monitoring activities.

Also, the 222-S Laboratory Complex will provide quality analytical chemistry services in support of Hanford processing plants with emphasis on waste management, chemical processing, and environmental monitoring programs at $\mathrm{B}$ Plant, $\mathrm{UO}_{3}$ Plant, Tank Farms, 242-A and 242-S Evaporators, Waste Encapsulation Storage Facility (WESF), PUREX, PFP, process development/upset activities, and essential materials.

\section{K.2 Description of the 222-S Laboratory}

The 222-S Laboratory Complex was constructed in 1950 to 1951 to provide analytical and plant support for the S-Plant Reduction-Oxidation (REDOX) Complex. Through the years, the missions of the 222-S Laboratory have changed, and modifications have been made in response to new requirements and to increasingly. restrictive operating and design criteria.

The design of the 222-S Main Building provides for all laboratory work to be done within the building. The building is provided with several support function shops for maintenance, instrument repair and service, electricians, millwrights, pipefitters, and glass work. Facilities for laboratory material storage, liquid and solid waste accumulation and storage, and filtration and exhaust are provided in areas adjacent to the 222-S Laboratory Building.

\section{K.3 Need for Upgrade}

This section is incomplete at this time. This section will be upgraded to provide a discussion of the extent to which the safety documentation does or does not meet the requirements of the Final Rules when this IP is upgraded to be the Rule Implementation plan.

\section{- K.4 Applicability of Technical Standards}

This section is incomplete at this time. This section will be upgraded to identify the applicability of the DOE technical standards identified in section 3.1 of this plan when this IP is upgraded to be the Rule Implementation Plan. 
WHC-SP-1164, Appendix K

\section{K.5 Basis for Interim Operations}

The following documents define the SAFETY BASIS for the 222-S Laboratory:

- WHC-SD-CP-HIE-001, Rev 0-E, "222-S Laboratories Facilities Hazards Identification and Evaluation,"

The ISB for the 222-S Laboratory has been prepared and submitted to DOE. The document is being reformatted and revised to incorporate additional guidance from DOE.

\section{K.6 Plan and Schedule for Upgraded SAR and TSRs}

This section is incomplete at this time. This section will provide the plan and schedule to develop the upgraded safety analysis when this plan is upgraded to be the Rule Implementation Plan. 


\section{Approval Signature}
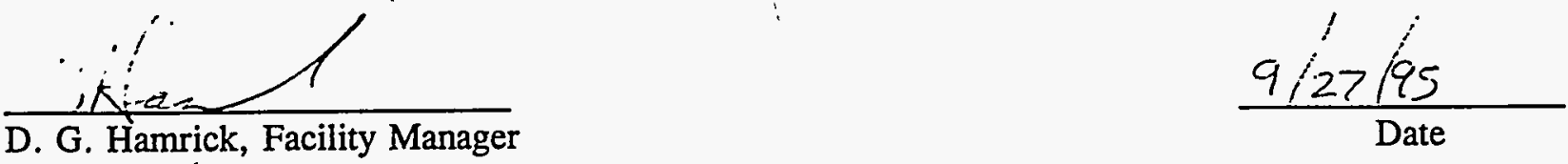


\section{L.1 Mission}

The $\mathrm{UO}_{3}$ storage facility stores uranium trioxide $\left(\mathrm{UO}_{3}\right)$ remaining after the deactivation and turnover of the $\mathrm{UO}_{3}$ facility to the Bechtel Hanford Company.

\section{L.2 Description of the $\mathrm{UO}_{3}$ Storage Area}

The $\mathrm{UO}_{3}$ storage facility remaining in custody of WHC consists of a metal storage building and its associated storage pads. Building $2714-\mathrm{U}$ is a metal storage building used to store depleted uranium in 208-liter drums on pallets stacked 2 high maximum. Drums containing sample bottles and chunks of solidified $\mathrm{UO}_{3}$ powder that were removed from the $\mathrm{H}$ calciner when it was cleaned out are also stored in the facility. The doors to the interior are secured with a SNM seal. The T-hopper storage pads are immediately north of, and border the 2714-U building. The gravel pad contains the empty T-hoppers and the concrete storage pad contains the full T-hoppers. The full T-hopper pad is surrounded by chain link fencing and has a railroad spur passing through the east side of the enclosure, through the provided gates, where the T-hoppers can be loaded onto bulkhead flatcars. A gate for forklift access is provided in the south fence just northwest of the 2714-U building. The empty T-hopper storage pad is located immediately west of the full Thopper storage pad and shares the chain link fence along that side. The remaining sides of the empty pad are also surrounded by a chain link fence which has a forklift access gate along the south side.

The T-hoppers when full each contain about 5.443 tonnes of $\mathrm{UO}_{3}$ powder. There are 147 full Thoppers and 38 empty T-hoppers stored in the two storage pad areas. A T-hopper assembly has a heavy metal framework about 1.5 meters square with a total height of about 2 meters. inside the framework is an inverted funnel shaped container. The bottom of the container has a gasketed circular metal cover and the top of the funnel neck has a gasketed metal cover. Both covers are secured by bolts. The total uranium in T-hopper storage is about 800 tonnes of $\mathrm{UO}_{3}$ powder.

\section{L.3 Need for Upgrade}

This section is incomplete at this time. This section will be upgraded to provide a discussion of the extent to which the safety documentation does or does not meet the requirements of the Final Rules when this IP is upgraded to be the Rule Implementation plan.

\section{L.4 Applicability of Technical Standards}

This section is incomplete at this time. This section will be upgraded to identify the applicability of the DOE technical standards identified in section 3.1 of this plan when this IP is upgraded to be the Rule Implementation Plan.

\section{L.5 Basis for Interim Operations}

The $\mathrm{UO}_{3}$ storage facility has defined the interim restrictions and operating controls for the deactivated state of the facility in WHC-SD-CP-ISB-003, "Interim Safety Basis for the Uranium Trioxide $\left(\mathrm{UO}_{3}\right)$ Powder Storage." The document has been sent to DOE for review and approval. 
WHC-SP-1164,

Appendix L

\section{L.6 Plan and Schedule for Upgraded SAR and TSRs}

This section is incomplete at this time. This section will provide the plan and schedule to develop the upgraded safety analysis when this plan is upgraded to be the Rule Implementation Plan. 